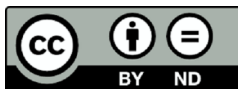

Acta Poloniae Historica

112,2015

PL ISSN 0001-6892

Robert Kasperski

Institute of History, Polish Academy of Sciences

\title{
ETHNICITY, ETHNOGENESIS, AND THE VANDALS: SOME REMARKS ON A THEORY OF EMERGENCE OF THE BARBARIAN GENS*
}

\begin{abstract}
There are two objectives behind this article. First, it seeks to trace down the pedigree of a theory described in scholarly discourse as the 'ethnogenesis model'. As is often believed, the theory originally was, essentially, an innovative concept proposed by Reinhard Wenskus, the German researcher. My article puts forth the idea whereby it was Walter Schlesinger who had laid the foundations for the theory, whose concept was further developed by Wenskus. My other purpose was to verify the basics of the theory itself, based on relevant empirical material; specifically, I mainly deal with original sources reporting on the ethnic composition and history of the Vandal people.
\end{abstract}

Keywords: ethnogenesis model, Reinhard Wenskus, Walter Schlesinger, ethnicity of the barbarian peoples, gens, Vandals

* My word of thanks goes to Professor Halina Manikowska of the Tadeusz Manteuffel Institute of History, Polish Academy of Sciences, Warsaw, for her valuable contribution to the discussion on this essay and offer to publish it with Acta Poloniae Historica. I am also indebted to Professor Roman Michałowski of the Institute of History, University of Warsaw, for having focused my attention on the ethnicity problems related to the Slavic peoples in the early Middle Ages. The underlying papers for this essay were delivered at a Polish-German conference 'Polish Historiography In the Face of the German Historic Science in the Nineteenth and Twentieth Centuries', held 26th-27th February 2010 in Łódź, as part of the collaboration between the Universities of Giessen and Łódź, and at the 11th Interdisciplinary Historical Seminar of 19 th to 21 st May in Hermanów. I am grateful to the organisers and contributors of these two scientific symposia for their critiques and all the comments and remarks they have shared. I am also deeply indebted to Professor Klaus Militzer, Universität zu Köln, for having sent me a useful biographical note of Reinhard Wenskus. 


\section{I \\ INTRODUCTORY REMARKS}

In one of his recent articles, the merited Austrian medievalist Herwig Wolfram describes the ethnogenetic processes that took place in the Early Middle Ages in the territory coincident with what is Austria today. ${ }^{1}$ The study raises a wide spectrum of problems related to the ethnicity of early medieval tribes in the era that began in the Antiquity and is nowadays adroitly described by scholars as 'the Transformation of the Roman World'. ${ }^{2}$ At the time, combined Roman-and-barbarian succession kingdoms emerged in the West Roman Empire area, which eventually came in place of the Roman Imperium. As Wolfram and his colleagues maintain, characteristic of this 'transformation' period were numerous ethnogenetic processes that led to transforming the face of the 'Roman world' and to the emergence of medieval Europe. ${ }^{3}$ Wolfram starts his considerations over the issues of ethnogenesis with a quote from the famous dictum of the American researcher Patrick J. Geary:

The Germanic world was perhaps the greatest and most enduring creation of Roman political and military genius. That this offspring came in time to replace its creator should not obscure the fact that it owed its very existence to Roman initiative, to the patient efforts of centuries of Roman emperors,

${ }^{1}$ Herwig Wolfram, 'Austria before Austria: The Medieval Past of Polities to Come', Austrian History Yearbook, xxxviii (2007), 1-12.

${ }^{2}$ Ibidem, 3. On the debate on ethnogenesis problems, see Andrew Gillett (ed.), On Barbarian Identity: Critical Approaches to Ethnicity in the early Middle Ages (Turnhout, 2002). This particular polemic triggered response from other scholars; see Wolf Libeschuetz, 'Debate about the Ethnogenesis of the Germanic Tribes', in Hagit Amirav and Bas ter Haar Romeny (eds.), From Rome to Constantinople: Studies in Honour of Averil Cameron (Leuven, 2007), 341-56 (rpt. in idem, East and West in Late Antiquity: Invasion, Settlement, Ethnogenesis and Conflicts of Religion [Leiden, 2015], 85-100); Peter Heather, 'Ethnicity, Group Identity, and Social Status in the Migration Period', in Ildar H. Garipzanov, Patrick J. Geary, and Przemysław Urbańczyk (eds.), Franks, Northmen, and Slavs: Identities and State Formation in Early Medieval Europe (Turnhout, 2008), 17-49. See also Walter Pohl, 'Goths and Huns', in Jeremy McInerney (ed.), A Companion to Ethnicity in the Ancient Mediterranean (Chichester, 2014), 555-68.

3 There are several synthetic studies on this period worth reading; see Walter Goffart, Barbarian Tides: The Migration Age and the Later Roman Empire (Philadelphia, 2006); Guy Halsall, Barbarian Migrations and the Roman West, 376-568 (Cambridge, 2007); Edward James, Europe's Barbarians, AD 200-600 (Oxon and New York, 2014). 
generals, soldiers, landlords, slave traders, and simple merchants to mold the (to Roman eyes) chaos of barbarian reality into forms of political, social, and economic activity which they could understand and, perhaps, control. ${ }^{4}$

Those who are familiar with the scholarly output of members of the 'Viennese School' (also known as the 'school of ethnogenesis') will not be astonished with the Geary quote, as it oftentimes appears in publications from this circle. Yet, Wolfram's article completely ignores the name of Reinhard Wenskus (1916-2002), the scholar who is inextricably bound up with the ethnogenetic theory. ${ }^{5}$ A signum temporis, perhaps? Have 'the Viennese' already moved away from the one described as 'the father of the ethnogenesis theory'? ${ }^{6}$ Have the arguments put forth in Stammesbildung und Verfassung (completed in 1959, first published 1961), been left on the shelf, the theories

${ }^{4}$ Patrick Geary, Before France and Germany: The Creation and Transformation of the Merovingian World (New York and Oxford, 1988), vi; also, see idem, 'Barbarians and Ethnicity', in Glen W. Bowersock, Peter Brown, and Oleg Grabar (eds.), Interpreting Late Antiquity: Essays on the Postclassical World (Cambridge, 2001), 107-29; idem, 'Ethnic Identity as a Situational Construct in the Early Middle Ages', Mitteilungen der anthropologischen Gesellschaft in Wien, 113 (1983), 15-26.

${ }^{5}$ Reinhard Wenskus, Stammesbildung und Verfassung. Das Werden der frühmittelalterlichen gentes (Köln and Graz, 1961). For the most important reviews of the study, cf. John M. Wallace-Hadrill, 'Review of R. Wenskus, Stammesbildung und Verfassung', English Historical Review, lxxix, 310 (1964), 137-9; František Graus, 'Review of R. Wenskus, Stammesbildung und Verfassung', Historica, 7 (1963), 185-91; Rolf Hachmann, 'Review of R. Wenskus, Stammesbildung und Verfassung', Historische Zeitschrift, cxcviii, 3 (1964), 663-74. Also, see the comments proposed by František Graus in his monograph: idem, Volk, Herrscher und Heiliger im Reich der Merowinger. Studien zur Hagiographie der Merowingerzeit (Praha, 1965), 314-36. Alexander C. Murray offers a critical discussion of Wenskus's theory: Alexander C. Murray, 'Reinhard Wenskus on "Ethnogenesis", Ethnicity, and the Origin of the Franks', in Gillett (ed.), On Barbarian Identity, 39-68. See also Eve Picard, Germanisches Sakralkönigtum? Quellenkritische Studien zur Germania des Tacitus und zur altnordischen Überlieferung (Heidelberg, 1991), 13, 30-1, 102, the latter being an excellent discussion of the 'sacral kingship' theory. Furthermore, see Stefan Arvidsson, Aryan Idols: Indo-European Mythology as Ideology and Science (Chicago and London, 2006), $178-238$.

${ }^{6}$ On Wenskus's life, see Heinrich Beck, 'Wenskus, Reinhard', in Reallexikon der Germanischen Altertumskunde, xxxiii (Berlin, 2006), 454-7; Hans Patze, 'Geleitwort', in Reinhard Wenskus, Ausgewählte Aufsätze zum frühen und preußischen Mittelalter. Festgabe zu seinem siebzigsten Geburtstag, ed. Hans Patze (Sigmaringen, 1986), xi-xii; Klaus Militzer, 'Reinhard Wenskus', Preußenland, xli (2003), 64; Ian Wood, The Modern Origins of the Early Middle Ages (Oxford, 2013), 300-1. 
proposed by other scholars being on the leading edge in the Viennese scholarly circle instead? ${ }^{7}$ While none of the notes in Wolfram's article mentions a single work by the famous German scholar, the arguments and findings offered in Wenskus's opus magnum continue, as will be demonstrated (as a collateral purpose hereof), to shine through the studies by 'Viennese School' authors. ${ }^{8}$ This essay discusses, at some length, the ethnogenetic model itself, with its (so to tentatively name it) historiographical genealogy. ${ }^{9}$ This will enable us to verify the view whereby Wenskus is the actual 'father', originator, of the model. Our considerations will also aim, however, at verifying the underlying assumptions of the model, as presented by Wolfram in the most recent edition of his monograph on Goths as well as in

${ }^{7}$ The monograph was republished in 1977. The theory proposed by Wenskus has been subject to several alternative takes, e.g. Michael Kulikowski, Rome's Gothic Wars (Cambridge, 2007); Patrick Amory, People and Identity in Ostrogothic Italy, 489-554 (Cambridge, 1997).

${ }^{8}$ In the most recent edition of his monograph on Goths, Herwig Wolfram rejects, however, the term Traditionskern (the 'kernel of tradition'), coined by Wenskus; Herwig Wolfram, Die Goten. Von den Anfängen bis zur Mitte des sechsten Jahrhunderts. Entwurf einer historischen Ethnographie (München, 2009), 12.

${ }^{9}$ The potential bibliography concerning the ethnogenesis model and its related issues is enormous; hence, only the major works are enumerated below: Andrew Gillett, 'Ethnogenesis. A Contested Model of Early Medieval Europe', History Compass, iv, 2 (2006), 241-60; idem, 'Introduction: Ethnicity, History and Methodology', in idem (ed.), On barbarian Identity, 1-18; Peter J. Heather, 'Merely an Ideology? - Gothic Identity in Ostrogothic Italy', in Sam J. Barnish and Federico Marazzi (eds.), The Ostrogoths from the Migration Period to the Sixth Century. An Ethnographic Perspective (Woodbridge, 2007), 31-60; Susan Reynolds, 'Our Forefathers? Tribes, Peoples, and Nations in the Historiography of the Age of Migrations', in Alexander C. Murray (ed.), After Rome's Fall. Narrators and Sources of Early Medieval History (Toronto, 1998), 17-36; Magali Coumert, 'Lidentité ethnique dans les récits d'origine: l'exemple des Goths', in Véronique Gazeau, Pierre Bauduin, and Yves Modéran (eds.), Identité et ethnicité. Concepts, débats historiographiques, exemples (IIIe-XIIe siècle) (Caen, 2008), 49-73; Timothy Reuter, 'Whose Race, Whose Ethnicity? Recent Medievalist' Discussions of Identity', in Timothy Reuter and Janet L. Nelson (eds.), Medieval Polities \& Modern Mentalities (Cambridge, 2006), 100-8; Helmut Castritius, 'Stammesbildung, Ethnogenese', in Reallexikon der Germanischen Altertumskunde, xxix (Berlin and New York, 2005), 508-15; Michael Kulikowski, 'Barbarische Identität. Aktuelle Forschungen und neue Interpretationsansätze', in Michaela Konrad and Christian Witschel (eds.), Römische Legionslager in den Rhein- und Donauprovinzen - Nuclei spätantik-frühmittelalterlichen Lebens? (München, 2011), 103-11. 
a collection of essays Gotische Studien. Volk und Herrschaft im frühen Mittelalter, published a decade ago. ${ }^{10}$ To this end, we will make use of several sources that can provide some information on the political history and ethnic composition of the Vandal people, who under the command of king Genseric (Gaiseric; reigned 428-77) hewed out a kingdom for themselves in northwest Africa. ${ }^{11}$ To end with, a few (very loose) remarks will be proposed with respect to the ethnicity of barbarian tribes.

II

\section{ETHNOGENESIS AND ETHNOS IN THE ETHNOGENETIC THEORY}

Minted by Soviet scholars, the term 'ethnogenesis'12 is usually used to denote the emergence, formation and/or singling out of a specified linguistic or ethnic group. Although today's German historiography synonymises ethnogenesis with Stammesbildung, this has not always been the case. Wenskus differentiated between ethnogenesis (Ethnogenese), which he defined as emergence of a distinct language group (e.g., the Germans), and the process of 'emergence (or creation) of tribes' (Stammesbildung), which was central to his investigation. Herwig Wolfram has equated ethnogenesis with Stammesbildung, and

${ }^{10}$ Wolfram, Die Goten, passim; idem, Gotische Studien. Volk und Herrschaft im frühen Mittelalter (München, 2005). See also idem, 'How Many Peoples are (in) a People', in Walter Pohl, Clemens Gantner, and Richard Payne (eds.), Visions of Community in the Post-Roman World: The West, Byzantium and the Islamic World, 300-1100 (Farnham and Burlington, 2013), 101-8.

${ }^{11}$ These sources include Sancti Augustini Vita Scripta a Possidio Episcopo, ed. and trans. Herbert T. Weisskoten (Princeton, 1919); and, Procopius, 'De bello Vandalico', in idem, History of Wars. Books III and IV, ed. and trans. Henry B. Dewing, ii (London and New York, 1929).

${ }^{12}$ See Arnold Klees, 'Ethnogenese - Eine neue Sowjetwissenschaft', Osteuropa. Zeitschrift für Gegenwartsfragen des Ostens, iv, 3 (1954), 165-73; Yuri Slezkine, 'N. Ia. Marr and the National Origins of Soviet Ethnogenetics', Slavic Review, lv, 4 (1996), 826-62, esp. 846 (rpt. in Ronald Grigor Suny and Michael D. Kennedy (eds.), Intellectuals and the Articulation of the Nation [Michigan, 1999], 211-56). Otherwise, cf. Gillett, 'Introduction', 6, n. 9. The entry 'Ethnogenesis' in Charles A. Gallagher and Cameron D. Lippard (eds.), Race and Racism in the United States: An Encyclopedia of the American Mosaic (Santa Barbara, 2014), 422, is somewhat misconceived; as we are told, "The term ethnogenesis was coined by David Greenstone and made popular by Andrew Greeley in his 1974 book Ethnicity in the United States: A Preliminary Reconnaissance." 
thus we will only apply the former term. In the concept proposed by Wenskus and Wolfram, ethnogenesis is an open-ended process of emergence, transformation, and decomposition of any of the barbaric peoples (gentes).$^{13}$ According to these researchers, a barbarian people as such was an open-ended process, never ended in a definitive manner. ${ }^{14}$ Clearly, this concept of ethnogenesis was once extremely innovative; whether it was Wenskus who originally developed it, remains essentially undetermined.

The German ethnologist Wilhelm Mühlmann dealt, some time ago, with problems of ethnicity and ethnogenesis. Wenskus studied the works by this flagship exponent of the functionalist current in German anthropology, and quoted their fragments in his Stammesbildung und Verfassung. ${ }^{15}$ Mühlmann, in turn, has partly based his argument upon the theories proposed by the Russian anthropologist Sergei M. Shirokogoroff. ${ }^{16}$ The latter affirmed that ethnos - a people - is, essentially, in itself an open-ended process: "This is a PROCESS which only may result in the formation of ethnical units, and this process I have called ETHNOS." Also Wolfram and Wenskus regarded gens as an open-ended process. ${ }^{17}$ Did Wenskus draw the thought from Shirokogoroff via Mühlmann's considerations? For the time being, this question has to remain unanswered.

${ }^{13}$ Wenskus, Stammesbildung, 81; Herwig Wolfram, 'Ethnogenesen im Donauund frühmittelalterlichen Ostalpenraum', in Helmut Beumann and Werner Schröder (eds.), Frühmittelalterliche Ethnogenesen im Alpenraum (6. bis. 10. Jahrhundert) (Sigmaringen, 1985), 97-151, esp. 97.

${ }^{14}$ Wolfram, 'Ethnogenesen', 97: "Ethnogenesen, Stammesbildungen, sind offene Prozesse, die im Grunde nie zu einem festen Abschluß kommen"; the phrase "offene Prozesse" calls for attention.

${ }_{15}$ Particularly the study by Wilhelm Mühlmann, Methodik der Völkerkunde (Stuttgart, 1938).

16 Sergei M. Shirokogoroff, Psychomental Complex of the Tungus (London, 1935). I have got acquainted with this study based on the Web version, <http://www. shirokogorov.ru/s-m-shirokogorov/publications/psychomental-complex-tungus-02> [Accessed: June 16, 2014].

17 Walter Pohl, 'Conceptions of Ethnicity in Early Medieval Studies', in Lester K. Little and Barbara Rosenwein (eds.), Debating the Middle Ages: Issues and Readings (Oxford and Malden, MA, 1998), 13-24, esp. 17 (originally published in Archaelogia Polona, xxix (1991), 39-49). Wenskus quotes Shirokogoroff's study in the references list added in Stammesbildung, 624, whilst citing it in the notes after Wilhelm Mühlmann (Methodik der Völkerkunde); see, e.g., Wenskus, Stammesbildung, 93, n. 477 . 
Much attention has been given to the question whether Wenskus was actually one of those who first broke with the perception of tribe as a blood-based community: a homogeneous group which is de facto a biological community of origin. According to some researchers, Wenskus can be credited with having noticed - a revolutionary moment in science - that ethnoses were heterogeneous groups whose nature was, in essence, political. ${ }^{18}$ However, as aptly noticed by Alexander C. Murray, Wenskus would not claim the merit of breakaway with the concept of tribe as a homogeneous biological community. ${ }^{19}$ The German scholar himself mentions examples of studies published before 1961 (the year his Stammesbildung und Verfassung was issued) and rejecting the concept of 'organic ethnos', developed on the ground of a biological community of origin. ${ }^{20}$ Murray quotes titles of some other studies that appreciate the political, heterogeneous, and polyethnic character of barbarian peoples. ${ }^{21}$ Yet, in his rejoinder, Walter Pohl, a disciple of Wolfram's, emphasises that Murray

underrates the weight of the biological argument among German-speaking scholars even after 1945 (and indeed, into my own career as a scholar, which started around 1980), and the efforts needed to overcome the longstanding views held by the germanische Altertumskunde. ${ }^{22}$

But, this counterargument misses the target, in fact. Scholars, including German and, obviously, Austrian ones, noticed long before Wenskus that barbarian peoples were political organisms, rather than ethnic communities based on a biological community of origin. Let us quote a passage from Richard Drögereit's article which came out in print in 1959, two years before Wenskus had his study published:

Attention as moreover been paid to Stöbe's observation that the so-called historical German tribes are not a creation in the ethnic, but rather in

${ }^{18}$ Wenskus, Stammesbildung, ix: "Diese Stämme aber, die gentes der zeitgenössischen Quellen, waren - wenigstens der Idee nach - in erster Linie politische Einheiten".

${ }^{19}$ Murray, 'Reinhard Wenskus', 49-51.

${ }^{20}$ Wenskus, Stammesbildung, 15; Murray, 'Reinhard Wenskus', 51, n. 41.

${ }^{21}$ Murray, 'Reinhard Wenskus', 50.

${ }^{22}$ Walter Pohl, 'Ethnicity, Theory, and Tradition: A Response', in Gillett (ed.), On Barbarian Identity, 221-39, here 224. 
a political, sense. Whilst this observation is not quite new, it is worthy of attention. ${ }^{23}$

Wenskus, as he himself admitted, said nothing new in this respect, in terms of international historiography, in general, or German historiography, in particular.

A political and heterogeneous character of early medieval tribes was noticed in the early twentieth century by Hector M. Chadwick; earlier on, in the nineteenth century, it was overall stated that medieval tribes were heterogeneous. ${ }^{24}$ In ethnology, this had been nothing new since long before the former half of the twentieth century. The same thing can be said of the historical science. For instance, George Vernadsky, American scholar of Russian background, wrote:

The tribe did not constitute a nation in the modern sense of the word. It could consist of clans of heterogeneous origin, even of different languages. For example, the Magyar horde in the eighth and ninth centuries of our era consisted of Ugrian, Turkish, and probably Alanic and Slavic clans. The tribe could be known under the name of its leading clan or under a new name. In many cases the tribe was called by the number of clans which formed it. ${ }^{25}$

${ }^{23}$ Richard Drögereit, 'Fragen der Sachsenforschung in historischer Sicht', Niedersächsisches Jahrbuch für Landesgeschichte, xxxi (1959), 38-76, here 46, n. 24; it is a commentary to a doctoral thesis on the history of the Saxons.

${ }^{24}$ In 1880, British amateur historian Henry H. Howorth described the conquest by the Mongols of 'heterogeneous tribes' of Caucasus: idem, History of the Mongols from the 9th to the 19th Century, Part 2: The So-Called Tartars of Russia and Central Asia (London, 1880), 103. The following passage is also worth citing here: "Our traditional history tells that we, the Celtic-speaking races of Britain, are not of one common ancestry, but are the descendants of two distinct series of immigrants, a British and a Gaelic. Whatever may have been the origin of the former, we know that the latter are not homogenous, but are the mixed descendants of the several Fomorian, Nemedian, Firbolg, Tutaha de Danaan, and Milesian immigrations, with which has been combined in later times a strong admixture of Scandinavian blood. It is now scarcely possible to ascertain to which of these component strains in our ancestry we owe the Celtic tongue which overmastered and supplanted the languages of the other tribes, but it is strictly in accordance with what we know of the history of mankind, that this change should have taken place. We have instances in modern times of adoption by conquered tribes of the language of a dominant people”, Alexander Macalister, 'The Study of Man', The Popular Science Monthly xlii, January (1893), 303-18, here 307.

${ }^{25}$ George Vernadsky, The Origins of Russia (Oxford, 1959), 21. Heterogeneous character of peoples was a universal truth in, e.g., the 1950s. This study was published, let us notice, two years before Wenskus's Stammesbildung came out. 
Vernadsky did not quote some revolutionary idea, given the context of the time: it was a universally known opinion on the character of nomadic/migrant peoples which had existed in historiography since the nineteenth century. ${ }^{26}$

III

WENSKUS'S MODEL: A NOVELTY, OR HISTORIOGRAPHICAL TRADITION CONTINUED?

There is yet another dispute taking place within the debate on early medieval barbarian tribes - the debate around the question whether the model proposed by Wenskus is an innovative formulation of the subject-matter or, rather, a continuation of the earlier German historiographical traditions. ${ }^{27}$ Before passing on, however, to a brief discussion of the scientific genealogy behind the model, let us try and jot its assumptions. In concord with his contemporary researchers, Wenskus rejected (as has already been said) the concept of tribe as a biological community of origin. Albeit members of a barbarian gens considered themselves a group founded upon the conviction that they were a 'community of origin' (Abstammungsgemeinschaft), they actually formed a heterogeneous group. ${ }^{28}$ The composition of barbarian gentes varied, and their members altered their ethnic identity, in time. As Wenskus believed, the assumption of an ethnicity, or tribal identity, was tantamount to the assumption of a specific tribal tradition.

The barbarians defined their own ethnic identity, and altered it by joining heterogeneous tribal unions ruled by royal lines. The emergence of a 'great tribe' (Großstammbildung) was connected with

${ }^{26}$ Robert L. Reynolds and Robert S. Lopez wrote on the polyethnic character of nomadic peoples as follows: "Even the identifications of the Hunni with the Hiung-nu and of the Avars with the Yuan-yuan are not definitely proved. We do perceive that all these tribes were so thoroughly commingled by intermarriage, migration, and conquest that we can scarcely speak of clear-cut ethnic border lines. At the most, we can speak of linguistic groups, as far as the Asiatic evidence goes", iidem, 'Odoacer: German or Hun?', The American Historical Review, lii, 1 (1946), 36-53, here 36-7.

27 See Murray, 'Reinhard Wenskus', 49-53.

${ }^{28}$ Wenskus, Stammesbildung, 14-17. Also, see Heinrich Beck, 'Probleme einer völkerwanderungszeitlichen Religionsgeschichte', in Dieter Geuenich (ed.), Die Franken und die Alemannen bis zur "Schlacht bei Zülpich" (496/97) (Berlin and New York, 1998), 475-88, esp. 476-7. 
activities of a small group acting as the carrier of tribal tradition. As per the model, the group is named Traditionskern - 'kernel of tradition'; in most, though not all, of the cases it was the royal line. The tribal tradition consisted of tribal genealogy, the gens's tribal name, a story of the gens's origin (origo), the genealogy of the royal line, and the remnants of ideological foundations of the former Germanic sacred kingship. ${ }^{29}$ The barbarians joining such a group assumed, with time, the ethnic identity of the royal line - or, of some other group that was the 'tradition bearer' within the given people. However, not only barbarian warriors changed their previous tribal identity into a new one: also the 'kernel of tradition'-forming group could alter their ethnic affiliation, though - as Wenskus remarked - this process was not as easy as with ordinary members of the tribe. ${ }^{30}$ Set at the centre of the ethnogenesis model was, indeed, the 'kernel of tradition', which could be the 'crystallisation core' for large tribal unions. As Wenskus puts it:

${ }^{29}$ Wenskus, Stammesbildung, 54-82. See Walter Pohl, 'Ethnic Names and Identities in the British Isles: A Comparative Perspective', in John Hines (ed.), The AngloSaxons from the Migration Period to the Eighth Century: An Ethnographic Perspective (Woodbridge, 2003), 7-32. I shall briefly digress at this point with respect to the Gothic Amals. There is no evidence that members of this dynasty considered themselves the descendants of a Scandinavian pagan god of war. However, the fact that their genealogy begins with the hero named Gapt has caused many a scholar to believe that the Scandinavian poetical name of Odin (odinsheiti), Gaut(r), is comprised underneath it; for more on the genealogy of the Amals, see Iordanes, 'De origine actibusque Getarum', in Iordanis Romana et Getica, ed. Theodor Mommsen (MGH, AA, v, 1 Berlin, 1882), c. 79, p. 76. The Jordanes's narrative equates the notions of semideus and heros with respect to Gapt and the other Amalian proceres, which is interesting in light of the fact that considering emperors as descendants of heroes was not alien to the imperial ideology. This is attested by a poem written for Trajan by his adoptive son Hadrian, naming the Roman emperor a 'descendant of Aeneas'; see 'Anthologia Graeca' $(6,332)$, in The Greek Anthology, trans. and ed. William R. Paton, i (London and New York, 1916), 474. In the Late Antiquity, Aeneas was also considered a hero and a demigod; e.g., we find the following description of Aeneas in Servius, author of commentaries to Virgil (4th/5th cc.): "Heros, vir fortis, semideus, plus ab homine habens, ut ait Hesiod", Commentarii in Virgilium Serviani sive commentarii in Virgilium qui Mauro Servio Honorato Tribuuntur (I, 194-201), ed. Heinrich A. Lion, 2 vols. (Göttingen, 1826), i, 42. The placement by the Amals of a demigod hero at the outset of their pedigree might have perhaps ensued from their adaptation of the ancient Roman ideology of power. After all, Theodoric the Great considered himself a Roman princeps.

30 Wenskus, Stammesbildung, 15. 
It may be clearly said that in all the cases an inconspicuous tradition-bearing kernel became the crystallisation point of a large tribal organism. This coincides with the findings of the ethnographers, who supply examples from many different parts of the world on how single and small 'traditiontransferring companies' raise powerful expansionary movements ... . ${ }^{31}$

In a note to the former of the two sentences, Wenskus quotes multiple literature items where he had spotted similar concepts. ${ }^{32}$ A study of importance for his own considerations was Thomas G. E. Powell's famous monograph on the Celts, ${ }^{33}$ which to some extent deals with the formation of barbarian peoples in Antiquity. ${ }^{34}$ According to this author, in the case of the Scythians and the Cimmerians, tribes of different background apparently merged under the rule of a pugnacious 'leading family' or 'royal tribe'. ${ }^{35}$ When the latter suffered a misfortune, the 'nation' would disintegrate, and then new groupings and tribal names would merge into heterogeneous populations. ${ }^{36}$ Powell has found processes analogous to the formation of the Scythians and Cimmerians in the formation of the Goths, Franks, and Angles. ${ }^{37}$ This author considered pagan beliefs to be the major bond linking these heterogeneous groups. The formation of such confederations of different tribes was, to his mind, reflected primarily through the changes in the Celtic pantheons. As he puts it: "Another and more complicative factor contributing to the development of the Tuatha Dé Danann would have been the political federation of several tribes or the emergence of a paramount tribe whose god would presumably have been thought to take into clientage the gods of the tutelary peoples." 38 Considering this observation, the similarities between it and the model presented by Wenskus are rather apparent. The German historian also noticed them, and this is why he quoted the British scholar's monograph. It is obvious that Powell based his considerations on the arguments voiced in the early twentieth century by the

${ }^{31}$ Ibidem, 75.

32 Ibidem, 75-6, n. 387.

33 Thomas G. E. Powell, The Celts (New York, 1958).

${ }^{34}$ For more on Powell see John D. Evans, 'In Memoriam Terence Powell', Proceedings of the Prehistoric Society, xlii (1976), iv.

35 Powell, The Celts, 51-2.

${ }^{36}$ Ibidem, 51.

37 Ibidem, 52.

38 Ibidem, 127. 
British researcher Hector M. Chadwick. ${ }^{39}$ It has already been noticed that Wenskus's ideas are partly convergent with those of Chadwick. ${ }^{40}$ In his famous 'trilogy' dealing with the history and institutions of the Anglo-Saxons, Chadwick proposed the following ideas:

i) early medieval peoples were originally not homogeneous groups; with time, however, all the ethnic or national differences blurred. For instance, there is no evidence, Chadwick argues, that any national differences existed among the Anglo-Saxons as they invaded the British Isles ${ }^{41}$;

ii) these peoples were ruled by royal lines deriving their origins from pagan deities $^{42}$;

iii) barbarian peoples of the Early Middle Ages tended to merge into religious confederations ${ }^{43}$;

iv) tribes were of a political nature ${ }^{44}$;

v) the fortune of the 'nation' was concurrent with the lot of its ruling dynasty: once the latter was overthrown, the 'nation' de facto ceased existing as a 'nation'. ${ }^{45}$

${ }^{39}$ Hector M. Chadwick, Studies in Anglo-Saxon Institutions (Cambridge, 1905); idem, The Origin of English Nation (Cambridge, 1907); idem, The Heroic Age (Cambridge, 1912); see Murray, 'Reinhard Wenskus', 53.

${ }^{40}$ Walter Pohl, 'Tradition, Ethnogenese und literarische Gestaltung: eine Zwischenbilanz', in Karl Brunner and Brigitte Merta (eds.), Ethnogenese und Überlieferung. Angewandte Methoden der Frühmittelalterforschung (Wien and München, 1994), 9-26, esp. 11, n. 8; idem, 'Conceptions', 16; Herwig Wolfram, 'Typen der Ethnogenese. Ein Versuch', in Geuenich (ed.), Die Franken, 608-27, esp. 609; Murray, 'Reinhard Wenskus', 53.

${ }^{41}$ Chadwick, The Origin, 89.

42 Ibidem, 145.

${ }^{43}$ Ibidem, 323. In addition, let us quote John B. Bury's argument: "The result was that the dense rings of forest, which isolated each state from its neighbours more effectually than the sea severs islands, were reduced to narrow limits with the expansion of the population, and the states were brought into a close proximity which facilitated and promoted political unions, whether intimate or loose. This process of grouping was perhaps favourable to the institution of royalty"; idem, The Invasion of Europe by the Barbarians: A Series of Lectures (London, 1928), 11.

${ }^{44}$ Chadwick, The Origin, 322.

${ }^{45}$ Ibidem, 172: "As a rule we may say that in early times the life of a nation hung together with that of its native dynasty. If the latter was overthrown the nation as a nation ceased to exist". Now, let us compare this statement against one of those proposed by Wenskus (Stammesbildung, 66): "Oft scheint es so, als ob das Bestehen des Stammes von der Existenz seines Herrschergeschlechts unmittelbar abhängig ist. Vielfach hört ein Stamm einfach auf zu existieren, wenn seine Dynastie verlischt". Let us notice, though, that the Alamans, who had lost 
Wenskus quotes in his work a study by Chadwick, which is however none of the three parts of the famous 'trilogy'. ${ }^{46}$ Even though we might accept that not all the studies authored by Chadwick were known to Wenskus, his mentor Walter Schlesinger was certainly an expert in Anglo-Saxon historiography. ${ }^{47}$ In one of his articles, Schlesinger faulted his German colleagues for not being acquainted with English-language historical studies, particularly those penned by Dorothy Whitelock and, of course, Chadwick. ${ }^{48}$ Schlesinger cited his 'trilogy' at various occasions. ${ }^{49}$ However, regardless of how deeply informed by the British historian Schlesinger's statements were - this point would call for more in-depth and broader research - it was this German scholar who had the strongest bearing on the theories that were finally forged into Stammesbildung und Verfassung.

In reality, though, the Wenskus's model follows up the theories proposed by his mentor. ${ }^{50}$ Schlesinger was an extremely well-read historian and often made effective use of English-language literature.

their king in a war against the Franks (which perhaps took place in 506-7) have not ceased to be an identifiable ethnic group that has not lost their ethnic distinctiveness and Alamanian identity within the regnum Francorum. Yet, it might be stressed, in favour of Wenskus's theory that possessing by this people of a stirps regia of their own is rather unlikely; see Dieter Geuenich, 'Der Kampf um die Vormachtstellung am Ende des 5. Jahrhunderts. Das Beispiel der Alemannen zwischen Franken und Ostgoten', in Theo Kölzer and Rudolf Schieffer (eds.), Von der Spätantike zum frühen Mittelalter: Kontinuitäten und Brüche, Konzeptionen und Befunde (Ostfildern, 2009), 143-62. For more on the Alamans within the kingdom of Franks, see Eugen Ewig, Die Merowinger und das Frankenreich (Stuttgart, 1988), $75,83$.

${ }^{46}$ Wenskus, Stammesbildung, 218, n. 527, quoting another study by Hector M. Chadwick, The Nationalities of Europe (Cambridge, 1945).

${ }^{47}$ Beck, 'Wenskus, Reinhard', 455. See also Patze, 'Geleitwort', xi.

${ }^{48}$ Walter Schlesinger, 'Randbemerkungen zu drei Aufsätzen über Sippe, Gefolgschaft und Treue', in Alexander Bergengruen and Ludwig Deike (eds.), Alteuropa und die moderne Gesellschaft: Festschrift für Otto Brunner (Göttingen, 1963), 11-59, esp. 21-41 (rpt. in idem, Beiträge zur deutschen Verfassungsgeschichte des Mittelalters, i [Göttingen, 1963], 286-334).

${ }^{49}$ Walter Schlesinger, 'Burgen und Burgbezirke. Beobachtungen im mitteldeutschen Osten', in idem, Mitteldeutsche Beiträge zur deutschen Verfassungsgeschichte des Mittalters (Göttingen, 1961), 158-88, esp. 183, n. 133 (first published in Werner Emmerich (ed.), Von Land und Kultur. Beiträge zur Geschichte des mitteldeutschen Ostens. Festschrift für Rudolf Kötzschke [Leipzig, 1937], 77-105).

${ }^{50}$ Beck, 'Wenskus, Reinhard', 455; Patze, 'Geleitwort', xi; Wenskus thanked Schlesinger in the introduction to his opus magnum, see idem, Stammesbildung, $\mathrm{x}$. 
The other scholars who, together with Schlesinger, formed the socalled Neue Verfassungsgeschichte (school for a 'new constitutional history'), Heinrich Dannenbauer being one of them, were also familiar with Chadwick's works, as Murray aptly points out. However, it was Schlesinger whose impact on the development of the theory nowadays known to us as the 'ethnogenesis model' was the most profound. ${ }^{51}$

In 1954, Schlesinger attended a conference which was focused on aspects of the legal and ideological foundations of early medieval monarchy. ${ }^{52}$ In an anthology issued (1956) in the aftermath of the conference, he published an article based on the paper he had delivered on that occasion; ${ }^{53}$ quoted below is a fragment of this text to help get a complete view of Schlesinger's merits in the creation of the ethnogenesis model. We should definitely state that without knowing the author, one could readily identify the following passage as coming from Wenskus. Schlesinger thus wrote of the formation of early medieval tribes:

Thus, the tribal moment has survived, and one primarily gains the impression that a tribal kernel occurred many a time, which has preserved the tribal tradition. To an extent, it was the kernel of crystallisation that was joined by alien tribal fractions, this taking place to a varied degree with different tribes. However, there are instances where nothing is known about the appearance of such a kernel.

51 Murray, 'Reinhard Wenskus', 54, n. 52.

52 Theodor Mayer, 'Vorwort', in idem (ed.), Das Königtum. Seine geistigen und rechtlichen Grundlagen (Lindau and Konstanz, 1956), 5 (2nd edn. 1965).

53 Walter Schlesinger, 'Über germanisches Heerkönigtum', in Mayer (ed.), Das Königtum, 105-41 (rpt. in idem, Beiträge, i, 53-87). See also idem, 'Herrschaft und Gefolgschaft in der germanisch-deutschen Verfassungsgeschichte', Historische Zeitschrift, clxxvi (1953), 225-75 (rpt. in Hellmut Kämpf (ed.), Herrschaft und Staat im Mittelalter [Darmstadt, 1956], 135-90). The first article referred to herein is complementary with the article by Otto Höfler, 'Der Sakralcharakter des germanischen Königtums’, in Mayer (ed.), Das Königtum, 75-104 (published also in La regalità sacra $=$ The Sacral Kingship. Contributi al tema dell' VIII Congresso internazionale di storia delle religioni, Roma, Aprile 1955 [Leiden, 1959], 664-701; and, in Otto Höfler, Kleine Schriften: ausgewählte Arbeiten zur germanischen Altertumskunde und Religionsgeschichte, zur Literatur des Mittelalters, zur germanischen Sprachwissenschaft sowie zur Kulturphilosophie und Morphologie, ed. Helmut Birkhan [Hamburg, 1992], 255-83). Höfler owed the popularity of his ideas in the field of medieval studies in post-war Germany to Schlesinger; see Picard, Germanisches Sakralkönigtum?, 27, n. 39. 
The kernel took care of preserving the tribal name, but with new large tribal associations, completely new names were produced. This phenomenon most probably refers, in pre-Christ time, to the Marcommani and afterwards, with the Alemanni, the Thuringii, possibly also for the Franks and, finally, the Bavarii; among the Saxons, the name of the core tribe has seemingly been retained. It is worthy of note, with respect to the Franks, that the royal line of the Merovingians followed the tradition of the Sugambri [Sicambri], whereas in the sphere of law, the Salians proved the tradition-shaping group. ${ }^{54}$

As is evident, this quotation comprises the same arguments which Wenskus presented in his habilitation thesis. According to Schlesinger, the ethnic tradition of a given people was retained in, and transferred through, the tribal core (gentiler Kern).

Also, the statements whereby a homogeneous people emerged out of a polyethnic army after the conquest of a coveted territory, the military king becoming a sacredly legitimised tribal monarch were not novel ideas, apparently first proposed with the publication of Stammesbildung und Verfassung. These ideas reverberate in Schlesinger's studies; one of which so comments on campaigns commanded by military monarchs, aiming to seize new lands for settlement:

When the venture proved successful, the settlement of the people and the formation of a state by this people being a success, then a new tribe emerged out of the tribal avalanche, and the war-king turned into the tribal king. ${ }^{55}$

Let us, moreover, quote the fragment of the idea expressed by the author in the note:

Differentiation should be made between the sacral tribal monarchy and the war-kingship, which oftentimes extended to members of several tribes and led to the formation of new tribes, even if, partly, under their old names. ${ }^{56}$

${ }^{54}$ Schlesinger, 'Über germanisches Königtum', 123. More insightful considerations on the Franks have been proposed by English-language authors; see Walter Goffart, 'Foreigners in the Histories of Gregory of Tours', Florilegium, iv (1982), 80-99 (rpt. in idem, Rome's Fall and After [London and Ronceverte, 1989], 275-92); Edward James, 'Gregory of Tours and the Franks', in Murray (ed.), After Rome's Fall, 51-66.

55 "Hatte das Unternehmen Erfolg, gelang die Niederlassung, die Reichsgründung, so entsteht aus dem Heerhaufen ein neuer Stamm, aus dem Heerkönig wird der Stammeskönig", Schlesinger, 'Herrschaft', 154.

56 "Zu scheiden sind sakrales Stammeskönigtum und Heerkönigtum, das häufig Angehörige mehrerer Stämme umfaßte und zur Bildung neuer Stämme, wenn auch teilweise unter altem Namen, führte"; ibidem, 154, n. 46. 
'Genuine'57 tribes were thus formed, we should even say (following the common concept of 'tribe'): no more heterogeneous but, indeed, homogeneous groups. Clearly, this thought had been put forth before Wenskus had his work published. What is more, this argument is a living idea; it can be found, for instance, in the recent studies by Wolfram; in one of them, this author finds that

These were, in particular, the kings who triggered these processes ${ }^{58}$ and, namely, the rulers of a peculiar type, who are referred to as the war-kings [Heerkönige]. They are continually presented as leaders of armies composed of multiple peoples (and, predominantly, of [several] types of weaponry). A model to follow for its neighbours: the Roman Empire was also a challenge and a threat to them, to which they would respond with invasive warfare or defensive struggle - long before the Great Migrations began. One example of an early aggressive war is the invasion of the Suebian leader Ariovistus, who in 70 B.C. crossed the Rhine with his motley troops, and encroached upon Gaul. Twelve years afterwards, [Julius] Caesar endeavoured to make this wealthy country a contentious territory. Ariovistus's attempt at forming in Gaul a new people out of his polyethnic troops failed in the clash with Caesar's art of field command. ${ }^{59}$

${ }^{57}$ The joke is based on the fact that tribe tended earlier on to be associated with culturally and ethnically homogeneous communities. The ethnogenesis model always has polyethnic armies become homogeneous formations, once they have victoriously seized their welcome land: "Es ist keine Neuheit, daß Theoderich nicht das Volk der Ostgoten, sondern ein römisches Föderatenheer nach Italien fürte, das mehrheitlich aus Ostgoten bestand. Als römischer Obermagistrat und König dieser Goten besaß Theoderich zwar alle Voraussetzungen, aus seinem Heer ein neues gotisches Volk zu machen. Die neue Ethnogenese vollzog sich aber unter Beteiligung von nichtgotischen Elementen"; Wolfram, Die Goten, 300. A similar take goes: "The territorialization of barbarian armies within these terms set into motion a further ethnogenesis. Barbarian kings began the attempt to transform the culturally disparate members of their armies into a unified people with a common law and sense of identity while maintaining their distance from the majority Roman population of their kingdoms. This identity was drawn from vague family traditions reinterpreted and transformed by the new situations in which they found themselves. For the Visigoths, the Balth family provided the center of this tradition. For the Vandals, it was the Hasdings; for the Ostrogoths, the Amals. These royal families projected their imagined past onto the people as a whole, providing a common sense of origin to be shared by the whole of the military elite", Geary, 'Barbarians', 121.

${ }^{58}$ This refers to the early medieval processes of emergence of ethnic identities.

${ }^{59}$ There are, nonetheless, a couple of problems to this theory; the major one being that there is no premise potentially in support of the statement that 
The thing is, any successful ethnogenesis makes numerous tribal foreigners - that is, members of ethnic minorities - into members of the tribe; monarchy facilitated as well as controlled the process. ${ }^{60}$

As is thus apparent, the theory whereby the military monarchy, having conquered its sought-for territory, proved capable of developing a new people out of the heterogeneous groups forming the barbarian army, continues to enjoy considerable popularity in the most recent studies authored by 'ethnogenesis school' exponents.

Were it not for the fact that it was Schlesinger who has penned the three quotations cited above, one could have thought that these excerpts come from Stammesbildung und Verfassung. The Wenskus's study, so designed by its author, was meant to present the thenexisting knowledge on the formation of the Germanic peoples. Rather than being an innovative concept, the book summarised the previous research on the political system, history, and religion of these peoples. It did not purport to break with the legacy arguments, statements or findings; instead, Wenskus endeavoured to present, in a concise and possibly coherent manner (with a partly eclectic outcome, though), the output that went to the credit of 'new constitutional history' (Neue Verfassungsgeschichte) scholars - particularly Walter Schlesinger, the trend's major representative.

Ariovistus's design was to form a new people out of his army. This army retained a division into tribes, as attested, for instance, by Caesar's account: "Tum demum necessario Germani suas copias castris eduxerunt generatimque constituerunt, paribus intervallis Harudes, Marcomanos, Triboccos, Vangiones, Nemetes, Sedusios, Suevos ..."; Gaius Julius Caesar, De bello Gallico, ed. George Long (London, 1857), I, 51, pp. 57-8. The medieval Mongols would serve as a better example of making a polyethnic army into a homogeneous people. Whilst Genghis Khan was, obviously, not the first leader form the Mongolian steppes who introduced the decimal system, he made of it an excellent instrument to debilitate and, to an extent, blur the tribal divisions among his warriors; see George Lane, Genghis Khan and Mongol Rule (Indianapolis, 2004), 8-10. Genghis certainly wanted to break the tribal structure and create a national army, as Richard A. Gabriel describes it, idem, Genghis Khan's Greatest General: Subotai the Valiant (Oklahoma, 2004), 26.

${ }^{60}$ Herwig Wolfram, 'Minderheiten - Erinnerungen an die europäische Frühzeit', in idem, Gotische Studien. Volk und Herrschaft im frühen Mittelalter (München, 2005), 280-92, here 284-5. 


\section{IV}

IN SEARCH OF THE BINDING/GENUINE DICTUM:

PATRICK J. GEARY VERSUS REINHARD WENSKUS

Although frequently quoted, the excerpt from Geary's book quoted at the outset of these considerations is not completely clear as far as the ethnogenesis problems is concerned. In Geary's view, "the Germanic world [was a] creation of Roman political and military genius". ${ }^{61}$ The endeavours of the Romans forged the chaos of the barbarian reality into a political, social, and economic activity they could comprehend and control. With regards to ethnogenesis as such, the subsequent passage in Geary's argument is key for us:

The barbarians themselves were for the most part particularly eager to participate in this process, to become 'authentic' peoples, that is, to achieve structures which made sense within the seductive orbit of classical civilization. So successful was this effort that already from late antiquity it was impossible for the Goths, Burgundians, Franks, and other 'peoples' who had become masters in the Western Roman Empire to understand themselves and their past apart from Roman categories of ethnography, politics, and custom, just as it was impossible for them to prosper apart from Roman traditions of agriculture and commerce or to exercise power apart from Roman traditions of politics and law. ${ }^{62}$

In his article cited at the beginning of this essay, Wolfram focused, to an extent, on the barbarian gentes. Always a polyethnic group in the Early Middle Ages - according to the Austrian scholar - gens was synonymous to the modern notion of 'people' and to the Latin notion of exercitus, that is, 'royal military following'. ${ }^{63}$ Following Geary's thought, these barbarian gentes only emerged as from the moment their members defined their own ethnic group with use of Roman ethnographic, political, and morals-related categories. Following, however, the subsequent reflections in Wolfram's essay, we come across another extremely interesting statement. In his consideration of the '(self-)transformation of the Roman World', Wolfram claims as follows:

61 See the remarks of Walter Goffart in idem, Barbarian Tides, 40-55, esp. 40.

62 Geary, Before France, vi.

63 Wolfram, 'Austria', 5. 
During the transformation of the Roman world, the Romans in the West became a people, a gens, among others. The constitutional concept of Roman identity was replaced by the notion of ethnicity based upon origins. ${ }^{64}$

The idea that the Romans became a gens in the course of the migrations of peoples reappears in Walter Pohl's article:

An inscription of the Berber King Masuna has been preserved in Altava and reads: 'rex gentium Maurorum et Romanorum'; the example set by the Vandal King's title is a remarkable as the integration of the Romans, who were considered as an ordinary people - gens - among others. ${ }^{65}$

But why should the Romans in the West have become a people only in late Antiquity, when the 'Roman World' was getting transformed? Were they not capable of defining their ethnic-and-political community similarly to what the barbarian tribes did, which - according to Geary, became 'genuine peoples' once the Roman ethnographic categories entered the stage? Posing such questions is patently nonsensical, for a prosaic reason: the theory of emergence of the Roman gens during the migrations is taken from a completely different historiographic tradition and has nothing in common with the American medieval studies of the sort proposed by Geary. Wolfram and Pohl founded their arguments upon another famous dictum, authored by Reinhard Wenskus:

The 'Gentilismus' [ethnic consciousness] of the conquering (landnehmenden) peoples was a politically stronger conception (Denkform) than the Roman imperial consciousness (Reichsbewußtsein) of the provincials. ${ }^{66}$

The barbarian peoples, which considered themselves origin-based communities, harnessed the Romans as well into their mental category, and the Romans were ever since considered one of the many gentes. According to Wenskus, the Romans became one of the gentes in the Late Antiquity and Early Middle Ages, since the barbarian peoples that invaded the Roman territory brought along a new

${ }^{64}$ Ibidem, 6.

65 Walter Pohl, 'The Vandals: Fragments of a Narrative', in Andrew H. Merrills (ed.), Vandals, Romans and Berbers: New Perspectives on Late Antique North Africa (Aldershot and Burlington, 2004), 41.

${ }^{66}$ As translated by Walter Goffart, in idem, Barbarian Tides, 227. 
political conception, which was ethnicity - hidden under the term Gentilismus used by the German historian. ${ }^{67}$ In the migrations era, Romanness became harnessed into the political thought pattern of the barbarian gentes. It was precisely from that moment onwards that the Romans became considered to be a 'gens' or, to be more specific, a community of origin. Was it really the case? The error committed by Wenskus and his mental followers, Wolfram and Pohl, consists in that they a priori denied Romans an ethnic identity. As it can be supposed, the Roman gens emerged only after the barbaric people brought along an ethnicity concept that allowed to define the Romans as a group founded on the belief that its members were an origin-based community. ${ }^{68}$ According to them, the Roman identity was a constitutional concept. This is what the ethnogenesis theory.

The truth is that a Roman ethnic identity existed both in the Empire era as well as in the Republic time. ${ }^{69}$ Moreover, a Roman gens - the gens Romana - whose primogenitor was the legendary Aeneas, also existed. ${ }^{70}$ We can easily identify the traditions among the Romans which derived the Roman gens -an ethnic community, from a mythical ancestor; yet, in turn, an author like Gregory of Tours was not aware of the earliest king of the Franks, or of the myth that would have reported on some legendary forefather of that people. ${ }^{71}$ Was it the case, then, that the barbarians brought over the classification categories related to ethnicity, or rather, had they taken them over from the sphere of ideas prevalent in the Mediterranean region? In his interesting deliberations, Johannes Fried stated that there was a different rationale behind the Franks believing, in the Carolingian

${ }^{67}$ Wenskus, Stammesbildung, 2: “... Gentilismus ... die besondere völkerwanderungszeitliche germanische Form des ethnischen Bewußtseins ...”.

${ }^{68}$ On the origin-based communities, see Steve Fenton, Ethnicity (Cambridge, 2010), passim.

${ }^{69}$ Emma Dench, Romulus' Asylum: Roman Identities from the Age of Alexander to the Age of Hadrian (Oxford, 2005), 222-97; Gary D. Farney, Ethnic Identity and Aristocratic Competition in Republic Rome (Cambridge, 2007), passim. As Myles Lavan notes: "The role of ethnicity in Roman discourses of identity, too often ignored amid claims that being 'Roman' was a political or juridical identity, has recently been re-emphasised ..."; idem, Slaves to Rome: Paradigms of Empire in Roman Culture (Cambridge, 2013), 34, n. 43.

${ }^{70}$ Ingo Gildenhard, Virgil, Aeneid, 4. 1-299: Latin Text, Study Questions, Commentary and Interpretative Essays (Cambridge, 2012), 51.

${ }^{71}$ See Murray, 'Reinhard Wenskus', 64-5. 
time, that the entire World was populated by gentes led by kings. ${ }^{72}$ The conviction that each of the groups neighbouring on the Franks was a gens ruled by a king (the Franks went as far as believing that all the Spanish Moors constituted a gens ruled by a rex Sarracenorum ${ }^{73}$ ) resulted from certain interpretative patterns and perception categories taken over from elsewhere - their source not being a remote barbarian North, though. According to Fried, the Franks had taken over these concepts from their ancient, patristic, and contemporary masters. ${ }^{74}$ Juxtaposing the dictum proposed by Geary against the one written down by Wenskus, one easily comes to the conclusion that they represent two contradicting theories. Why, then, do both of these statements coexist in the 'Viennese School' articles on equal terms, and references are made to both within one essay or another? Walter Pohl gives one possible answer in an article being a rejoinder to the charges aimed at the 'Viennese School' by the scholars associated with Walter Goffart - the so-called Toronto School:

It was precisely Herwig Wolfram who underlined the Roman foundations of the Gothic kingdoms, contrary to the views held by Höfler, Schlesinger, and Wenskus. Patrick Geary's 'mantra' that 'the Germanic world was perhaps the greatest and most enduring creation of Roman political and military genius' sketches a new paradigm that is contrary to all that $\mathrm{Höfler}^{75}$ ever believed. ${ }^{76}$

72 Johannes Fried, 'Weshalb die Normannenherrscher für die Franken unvorstellbar waren', in Bernhard Jussen (ed.), Die Macht des Königs. Herrschaft in Europa vom Frühmittelalter bis in die Neuzeit (München, 2005), 72-82.

73 See Hans-Werner Goetz, 'Sarazenen als "Fremde"? Anmerkungen zum Islambild in der abendländischen Geschichtsschreibung des frühen Mittelalters', in Benjamin Jokisch, Ulrich Rebstock, and Lawrence I. Conrad (eds.), Fremde, Feinde und Kurioses. Innen- und Außenansichten unseres muslimischen Nachbarn (Berlin, 2009), 39-66, esp. 50-2.

${ }^{74}$ Fried, 'Weshalb die Normannenherrscher', 80.

75 Otto Höfler was an Austrian folklorist and Germanist. He closely collaborated with Heinrich Himmler, head of the SS, on the Ahnenerbe project. Höfler advocated the 'continuation thesis' which claimed that the German history had retained its continuity from a prehistoric time until the twentieth century. He has also found that Germanic peoples - or rather, the 'Nordic race' predominant amongst them - had unique state-forming capacities. He thence stressed that the early medieval statehood had Germanic, rather than Roman, roots. See idem, 'Das germanische Kontinuitätsproblem', Historische Zeitschrift, clvii (1938), 1-26. With respect to the continuity argument, see the commentaries in Walter Pohl, Die Germanen 
As may be inferred from this quotation, Geary's statement is a peculiar alibi protecting 'Viennese School' exponents against the charges, voiced over and over again, of a nationalistic character of the historiographic domain pursued by them, which is referred to as 'Germanic antiquities' (germanische Altertumskunde). ${ }^{77}$ This statement moreover sufficiently firmly demonstrates, to all and sundry, that the 'Viennese School' accepts that the Roman World once played some part (be it larger or smaller) in the ethnogenesis of the early medieval gentes. This being the case, Geary's dictum may (re)appear in the same studies which remind of the Wenskus-made good old claim of Romanness having been harnessed into the concept of (political, to be sure) ethnicity that was brought over by the Germanic barbarian peoples. ${ }^{78}$

(München, 2004), 66-7. The question remains open to what extent Wenskus's and Schlesinger's statements highlighting the role of the Germanic peoples' ethnic tradition in the formation of medieval Europe have been an attempt to transform the Germanic continuation idea into a more approachable and less controversial theory. See Murray, 'Reinhard Wenskus', passim. Let us moreover quote František Graus at this point: "Als Elemente der germanischen Kontinuität nennt H. Mitteis: das charismatische Volkskönigtum, den germanischen Adel und seine 'biologische Substanz', die Gefolgschaft und Treue, Burgen und Höfe des Adels, das in der adeligen Kirchenherrschaft fortlebende Erbcharisma des Adels. Diese vermeintlich gesicherten Elemente verbürgen seiner Ansicht nach 'die Kontinuität der germanischen Verfassungsgrundlagen”, idem, 'Über die sogenannte germanische Treue', in Hans-Jörg Gilomen, Peter Moraw, and Rainer C. Schwinges (eds.), Vorträge und Forschungen: Ausgewählte Aufsätze von František Graus (Stuttgart, 2002), 133-79, here 134 (first published in Historica, 1 [1959], 71-122).

${ }^{76}$ Pohl, 'Ethnicity', 225.

${ }^{77}$ Walter Pohl also discerns the 'nationalists' in contemporary science: “... although nationalist ideologies have not completely retreated from academic studies of ethnicity, and have regained some ground recently, especially in Eastern Europe", idem, 'Ethnic names', 7.

${ }^{78}$ Pohl thus expresses his objections with regards to the ethnogenesis theory by Wenskus: "I have proposed four points in which I consider Wenskus's position untenable: (1) the concept of the Stamm indicates that these tribes were components of a German(ic) Volk or people, which I do not think existed in Late Antiquity or the early Middle Ages, except as a linguistic abstraction; (2) his elitist views implied in the idea of the Traditionskern; (3) his strong predilection for Geistesgeschichte, a German philosophical concept only vaguely rendered in English by 'history of ideas', which allowed a subjective definition of ethnicity, but implied that the ideology of Gentilismus was an almost metaphysical force of change; and (4) the schematic dichotomy of Roman and Germanic, and the almost exclusively Germanic interpretation of the history of Stammesbildung”, idem, 'Ethnicity', 224-5. 


\section{ETHNIC IDENTITY ALTERED: AN INSTRUMENTAL ETHNICITY MODEL AND THE SOURCE RELATIONSHIP PROBLEM}

Reinhard Wenskus can certainly be considered one of the numerous twentieth-century adherents of the model of instrumental ethnicity. ${ }^{79}$ According to this approach, humans driven by opportunistic calculation alter their ethnic identity in order to attain material and political benefits. Wenskus's view has it that ordinary warriors who formed the foundation of tribal masses were not the only ones who changed their ethnic identity. Also the tribal aristocracy, forming the leadership group called the 'kernel of tradition' could alter their ethnicity; yet, as the German scholar remarks, this was a much tougher process than in the case of ordinary representatives of a given people. ${ }^{80}$

Also Wolfram supports the model of instrumental ethnicity. Departing, however, from the rather complicated considerations proposed by Wenskus, Wolfram accepted Geary's argument that "In fact, ethnic identity is situational." ${ }^{81}$ The barbarian ethnicity was, in Wolfram's and Geary's concept, a political strategy applied in order to achieve suitable benefits. Hence, the barbarians often altered their ethnic identities. Putting it bluntly, someone could have been a Goth and subsequently switch, in identity terms, into an Alan, a Vandal, or a Gepid. Wolfram thus describes these processes:

The Goths in both Italy and southern France consisted of at least ten different ethnic groups who all shared in the Gothic identity called libertas Gothorum. Or, a Roman lady with a Longobard name sold property with the consent of her husband with a Roman name according to Longobard law, because it fit her purpose better than the Roman code. An Avar kept his identity as long as he stayed pagan, sat in the saddle, and acted as lord, irrespective of the language he spoke, be it Turkish, Slavic, Germanic, a Romance language, or some other unknown vernacular. In contrast, a Christian Avar lost his identity embodied by the khagan. He changed his ethnicity to become Bavarian, Slav, or Roman. In sum, the Viennese apply the term ethnic to describe ancient and medieval 'peoples in progress', not modern nations or their mostly recent ethnic subdivisions. ${ }^{82}$

${ }^{79}$ Wenskus, Stammesbildung, 78-82.

${ }^{80}$ Ibidem, 78.

${ }^{81}$ Wolfram, 'Austria', 5.

${ }^{82}$ Ibidem. Is ethnicity political only? Can individuals alter their ethnic affiliation at liberty? With regard to the latter question, let us note that somebody aspiring 
This instance of identity alteration was enabled by the activity of the royal line, which was the main driver behind the ethnogenesis processes (according to the theory's assumptions); in a somewhat different concept, the underlying factor was the actions of the institution called war-kingship. ${ }^{83}$ The barbarian gentes were of a polyethnic character, as they were formed of members of various ethnoses. However, this multiethnic nature of each early medieval gens tended to wane after some time, its members assuming the ethnic identity cultivated by their spearheading military monarch.

In the view of the ethnogenesis model's followers, the war-kingship (Heerkönigtum) was one of the two (or, three - should the sacral monarchy be regarded as a type of its own) types of the archaic Germanic monarchy. ${ }^{84}$ It distinctly differed from the other type, called the tribal monarchy (Volkskönigtum) - a monarchy whose sacral taint was evident. ${ }^{85}$ Walter

to become a member of a tribe must be first regarded as such by the other members. Christina Gish Berndt's very interesting considerations on the Cheyenne people are worth quoting at this point: "If a person had been around the Cheyenne way of living long enough and had let this way of living into his or her heart, there could be possibility this person would be considered Cheyenne. Cheyenneness has been considered a condition of the heart, in part, a state of being, not based on birth and not based on a political contract. Therefore, Cheyenne identity could fluidly incorporate outsiders who had taken enough time and effort to allow the Cheyenne way into their hearts. Cheyenne identity was not simply a way of being, however; it also had to be recognized by others"; eadem, Kinship as Strategic Political Action: The Northern Cheyenne Response to the Imposition of the Nation-State (Ann Arbor, 2008), 46. However, as she notes further on: "Over time, a person recognized as non-Cheyenne could become like-hearted and be recognized as Cheyenne by people both within and outside of the nation. Such people were incorporated from outside the nation through intermarriage and adoption", ibidem.

${ }^{83}$ Wolfram, 'Minderheiten', 284.

${ }^{84}$ Herwig Wolfram, 'Rom und das frühe Königtum nördlich der Alpen', in idem, Gotische Studien, 15-65. This essay is composed of two earlier published sketches: idem, 'Frühes Königtum', in Franz-Reiner Erkens (ed.), Das frühmittelalterliche Königtum: ideelle und religiöse Grundlagen (Berlin, 2005), 42-64 (also published in Heinz Duchhardt and Wilfried Reininghaus [eds.], Stadt und Region: internationale Forschungen und Perspektiven; Kolloquium für Peter Johanek [Köln, Weimar, and Wien, 2004], 111-25); and, idem, 'Markomannen und Quaden nach dem "Großen Krieg". Spurensuche nach einer Verfassung', in Herbert Heftner and Kurt Tomaschitz (eds.), Ad fontes!: Festschrift für Gerhard Dobesch zum fünfundsechzigsten Geburtstag am 15. September 2004 (Wien, 2004), 783-90.

${ }^{85}$ The sacral monarchy (Sakralkönigtum) is often regarded as identical to the tribal monarchy (Volkskönigtum), whilst Volkskönigtum is seemingly identical with 
Schlesinger was quite a time ago preoccupied with the substance of war-kingship, and wrote an article focused on this topic. ${ }^{86}$ Many years later, Wolfram characterised this model of monarchy in a much more straightforward way. In contrast to the 'tribal monarchy', whose authority extended to a defined barbarian ethnic group, typical of 'military monarchy' were the criteria such as polyethnicity of its subordinate army, a clearly laid-out bodyguard retinue structure, power exercised over the other peoples, and monarchical superior authority (suzerainty) in the course of war. ${ }^{87}$

In his deliberations, Wolfram gives military monarchy the central role in changing the ethnic character of the polyenthic armies led by 'military kings' such as Theoderic the Great (d. 526), Genseric (d. 477), or Alaric I (d. 410/411). These processes took the following course, in Wolfram's concept:

When successful, ethnogenesis forms - in lieu of a number of aliens, originally members of the original minorities - a consolidated tribal group of members; the kingdom having facilitated, and controlled, the process. ${ }^{88}$

For an ethnogenesis to be complete, or successful, would (in this case) be for the king of a polyethnic army to conquer a new homeland for his combaters and their families. Such a campaign would always be crowned by the emergence of a 'new people'. Putting it otherwise, a 'successful ethnogenesis' marked the formation of the Hasding Vandals, Amal Goths, or Merovingian Franks. With a new 'home country' gained, the polyethnic and heterogeneous character of the conquering barbarian army would gradually decline: the once-aliens became members of the local tribe through accepting the ethnic tradition that had been preserved by the king and his lineage. As has been shown, with Schlesinger's statement, this concept is, clearly, not a new one.

Let us resume at this point the discussion on the character of barbarian ethnicity within the ethnogenesis model: ethnicity comprehended in terms of a 'situational construct'. ${ }^{89}$ As Patrick Geary puts it,

Stammeskönigtum. For more on the problems with the potentially applicable terms, see Picard, Germanisches Sakralkönigtum?, passim.

${ }^{86}$ Schlesinger, 'Über germanisches Heerkönigtum', 105-41.

87 Wolfram, 'Rom', 42.

${ }^{88}$ Idem, 'Minderheiten', 284-5.

${ }^{89}$ See also Dick Harrison, 'Dark Age Migrations and Subjective Ethnicity: The Example of the Lombards', Scandia. Tidskrift för kritisk historisk forskning, lvii, 
the peoples of the migration period acquired their identity through their adherence to particular royal or ducal families alongside whom they fought and whose traditions their adopted. The actual circumstances in which ethnic designations seem to have been felt most acutely were largely political..$^{90}$

Not everybody shares the view that the ethnic identity of the barbarians was of an instrumental and political nature. Not all the scholars would agree with the argument, either. Critically inclined toward Wenskus and Wolfram, Murray sees the problem otherwise:

These ideas have been used by Patrick Geary in a study of ethnic terminology in the Frankish kingdom to argue that ethnicity was a malleable construct that was determined mainly by political circumstances and by the interests of lordship. The method depends on confounding the occasions when ethnicity is mentioned (in political narratives, these occasions tend unsurprisingly to be political and military) with the criteria for ethnicity, and on finding confusion and contradiction in the sources' attribution of ethnicity. The sources do not comply with the method. Their testimony tends to run doggedly to the banal, unambiguous, and conventional - ethnic association was something one was born into: a person was a Frank, a Roman, or a Burgundian by birth. ${ }^{91}$... It is hardly likely that ethnicity, whatever one is to make of its depth in society or the intensity of feelings it aroused, was simply an instrumental category and an attribute of royal ideology and political strategy. More often than not it seems to have had very little to do with political allegiance at all. ${ }^{92}$

Murray supports his statement with the chronicle of so-called Fredegar, which describe the ethnicity of a given figure with use of the word genere, e.g. 'genere Francus', 'genere Romanus'. ${ }^{93}$ As will be apparent

1 (1991), 19-36; Patrick Amory, 'Names, Ethnic Identity, and Community in fifthand sixth-century Burgundy', Viator: Medieval and Renaissance Studies, xxv (1994), $1-30$.

${ }^{90}$ Geary, 'Ethnic Identity', 24.

${ }^{91}$ Murray, 'Reinhard Wenskus', 58-9.

92 Ibidem, 59.

${ }^{93}$ There is an interesting instance of classing Ricimer (d. 472) in a panegyric in praise of Anthemius. It is namely stressed that the barbaric leader was paternally a Suevian and maternally a Goth. Cf. the 'Panegyric on Anthemius', cc. 360-2, in Sidonius Poems and Letters, trans., introduction, and notes William B. Anderson (Cambridge, MA, and London 1963), 38: "tum livet quod Ricimerem in regnum duo regna vocant; nam patre Suebus, a genetrice Getes" = "Especially he [i.e., Genseric] envies Ricimer because two kingdoms call him to kingship; for he is 
further on, also the category of birth marked the ethnic classification in other barbarian succession-based states. Three barbarians will be portrayed, of whom two were political clients of two royal families: the house of Visigoths and the dynasty of Hasdings, respectively. As we shall see, these barbarians were of 'foreign tribe' descent but eventually adapted none of the traditions of the two lineages, nor did they change their ethnic identity - albeit their political successes were pretty considerable.

Let us now leave the historiographic and theoretical deliberations over the ethnogenesis model. The other problem that calls for discussion is the theory of altering ethnic identity when influenced by monarchy. Our focus will be on the Vandals, who in 429 AD, led by king Genseric, crossed the Gibraltar Strait and landed in Africa. ${ }^{94}$

The Vandals are, in essence, a great problem for the ethnogenesis theory. There is no evidence that the kings of this people, the Hasdings, considered themselves a lineage deriving its roots from some pagan deities. As far as the account of the origin is concerned, there is, indeed, an account by Procopius of Caesarea concerning the migration of the Vandals from their former settlement area, located - as may be judged based on the historiographer's description - by the Azov Sea, and abandoned by them owing to famine; ${ }^{95}$ however, there are some important reasons to believe that it is not an authentic tribal saga (an origo, or Wandersage, as the ethnogenesis theory names it) of this people that we actually have to do with. In Procopius's version, the Vandals left their aboriginal home due to hunger and, in the course of their wandering, reached the north of Africa, where they finally settled down. But not all of the Vandals got underway, leaving their hearth and home: a group of this people remained in their former 'native land'. Some time afterwards, it was this very group, remaining in the territory of their 'original homeland', sent a legation to their kinsmen residing in Africa to try and persuade them to renunciate their right to the lands they had once deserted. Wenskus was of the opinion that this described a real story of the Vandal's itineration. ${ }^{96}$

Suevian through his father and Gothic through his mother"; the translation is quoted after: Penny MacGeorge, Late Roman Warlords (Oxford and New York, 2002), 238.

${ }^{94}$ Ludwig Schmidt, Geschichte der Wandalen (Leipizg, 1901), 36.

${ }^{95}$ Procopius, 'De bello Vandalico', III, 3, 1-2, pp. 22-3.

${ }^{96}$ Wenskus, Stammesbildung, 67. 
However, as Walter Goffart has shown, Procopius's account comprised "the motif of a barbarian people returning to their former abode" and, for this reason, it stood for a narrative strategy which was used by Procopius as part of a debate going on in the 550s in Constantinople with regard to the tomorrow of the barbaric peoples. ${ }^{97}$ The story of the Vandals' migration is, in all probability, not a tribal saga (Stammessage) of this particular people. ${ }^{98}$ As for the very capacity of transforming polyethnic groups into a 'new', and homogeneous, people, the history of the Hasdings would be too tough to crack for those supporting the ethnogenesis model.

Frank M. Clover, one of the most merited researchers into the African Vandal state, wrote once that the Vandals formed a polyglottic group, rather than a homogeneous unity. ${ }^{99}$ And indeed, the subjects of the Hasding kings formed a polyethnic army, a polyethnic barbarian collectivity that consisted of at least three groups (or, possibly, more, as the Suebi might have been among the Vandals as well ${ }^{100}$ ). The first was, obviously, the Hasdings, considered one of the two (or three) peoples that were referred to as 'Vandals' (the other being the Silings; some scholars consider the mysterious gens of the Lacringi to have been the third). The Hasding branch yielded the kings of the

${ }^{97}$ Goffart, Barbarian Tides, 108. For more on this debate, with contributions from Jordanes, see Walter Goffart, The Narrators of Barbarian History (A.D. 550-800): Jordanes, Gregory of Tours, Bede, and Paul the Deacon (Publications in Medieval Studies, Notre Dame, 2005), 84-96; Andrew Gillett, 'The Goths and the Bees in Jordanes: A Narrative of No Return', in John Burke (ed.), Byzantine Narrative: Papers in Honour of Roger Scott (Melbourne, 2006), 149-63; Amory, People, 291-313.

${ }^{98}$ The Vandals inhabiting Africa were once visited by envoys sent by their kinsmen residing in their 'former homeland', in order to try and induce the 'African Vandals' to waive their right to their 'native lands'. Walter Goffart has mistakenly stated that "Procopius does not specify where the ambassadors came from or under which Vandal king of North Africa they came ...". The envoys came to Africa during the reign of King Genseric; see Procopius, 'De bello Vandalico', III, 22, 1-12, pp. 184-9. For a different approach of the story's historicity, see Felix Dahn, Die Könige der Germanen das Wesen des ältesten Königthums der germanischen Stämme und seine Geschichte bis auf die Feudalzeit. Die Zeit der Wanderung. Die Vandalen (München, 1861), 225-6; Schmidt, Geschichte der Wandalen, 17-18 and 152. Wenskus considers Prokopius's information on this legation to have been a historic fact; idem, Stammesbildung, 41-2, 45, 67; Helmut Castritius, Die Vandalen. Etappen einer Spurensuche (Stuttgart, 2007), 40-1.

${ }^{99}$ Frank Clover, The Late Roman West and the Vandals (Aldershot, 1993), 50.

100 Andrew Merrills and Richard Miles, The Vandals (Oxford, 2010), 86. 
Vandals, who were called stirps Hasdingorum. ${ }^{101}$ Apart from these, Alans formed a strong group in the state of the Vandals. The authority of the Hasding house over the two peoples is visible in the official title describing the Vandal kings: Rex Vandalorum et Alanorum, which is however attested only for King Huneric (reigned 477-84), ${ }^{102}$ and for the time of Gelimer, the last king of the Vandals (reigned 530-4) ${ }^{103}$. Apart from the Vandals and the Alans, the third barbaric group within the Vandal regnum were the Goths - the most 'sought after' characters in ethnogenetic deliberations.

With regards to the Alans, scholars have for long now been emphasising that the official title of the Vandal kings indicates that representatives of this people remained a separate group within the state of the Hasdings. This title proves, it is believed, that the Alans were a group that mattered, and preserved their ethnic singularity, within the Vandal regnum. ${ }^{104}$ This is testified also by Procopius of Caesarea who, as a secretary to Belisarius, joined the imperial army's campaign against the Vandals in 533-4. Writing of king Gelimer's army, Procopius oftentimes refers to the Vandals and the Alans mentioning these branches one alongside the other, which strongly suggests that the latter continued to form a separate identifiable group. ${ }^{105}$ What is more, the East Roman historiographer thus wrote of the Alans: "But the names of the Alani and all the other barbarians, except the Moors, were united in the name of Vandals." ${ }^{06}$ Thus, the name of Vandals functioned within the Hasding regnum in a dual sense: first, as the

${ }^{101}$ Cassiodorus, Variae epistolae, XI, 1, 2, ed. Theodor Mommsen (MGH, AA, 12, Berlin, 1894), 267.

102 On the titles used by the Hasdings, see Schmidt, Geschichte der Wandalen, 31 (n. 5), 163-4; Herwig Wolfram, Intitulatio I. Lateinische Königs- und Fürstentitel bis zum Ende des 8. Jahrhunderts (Graz, Wien, and Köln, 1967), 41, 79-87; Andrew Gillett, 'Was Ethnicity Politicized in the Earliest Medieval Kingdoms?', in idem (ed.), On Barbarian Identity, 85-121, esp. 92-3.

${ }^{103}$ Procopius, 'De bello Vandalico', III, 24, 3, pp. 197-8. For Wolfram's comment, see idem, Intitulatio I, 81.

${ }^{104}$ Bernard S. Bachrach, A History of the Alans in the West: From Their First Appearance in the Sources of Classical Antiquity through the Early Middle Ages (Minneapolis, 1973), 57; Gillett, 'Was Ethnicity Politicized', 110, n. 31. Schmidt, in contrast, states that the Alans were Germanised but retained a singularity all the same; see idem, Geschichte der Wandalen, 35. Also, see Pohl, 'The Vandals', 42.

${ }^{105}$ Merrills and Miles, The Vandals, 84.

${ }^{106}$ Procopius, 'De bello Vandalico', III, 5, 21, pp. 52-3. 
name of a people that, together with the Alani, formed an army remaining under the command of the Hasding house kings; second, as a group name extending to all - save for the Moors - barbarian groups subordinate to the authority of Genseric and his offspring.

Let us refocus now on the Goths within the Kingdom of Vandals. Possidius of Calama (d. 437), who eye-witnessed the Vandals' invasion on Africa, tells us that the ethnic composition of the Hasding army was as follows:

It so occurred, within a rather short time, out of divine will and powerfulness, that, armed with diverse weaponries and experienced in warfare, a great host of savage enemies, the Vandals and the Alani, blended with some of the Goth people and with other diverse persons, has arrived on vessels from Spain and, having crossed the sea, sailed into Africa, and attacked it. ${ }^{107}$

The Goths in the ranks of Genseric's army: what was their background, Ostrogothic, or, Visigothic? The German scholar Ludwig Schmidt supposed, on a well-informed basis, that the Goths joining the Hasding army were part of the troops of the Gothic King Athaulf (d. 415) or his successor, Wallia (d. 418), which remained in Spain as most of these rulers' armed forces retreated to Gaul. ${ }^{108}$ Following the modern nomenclature, one should call them Visigoths. Did these Goths cease being of a 'alien tribe' after Genseric subdued the northern African territory - and, influenced by the Hasding house monarchs, did they assume a Vandal ethnic identity? Putting it otherwise, had they been Vandals, rather than Goths, ever since? There is a lot in support of the view that, like the Alani, the Goths did not turn into Vandals, losing their ethnic identity. This view is reinforced by a certain Goth who sucked out a lot of blood from the Vandals on the island of Sardinia. A role of importance was played during Gelimer's reign by a certain Godas, whom the king made governor of the province of Sardinia. According to Procopius, Godas was a Goth

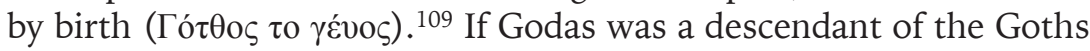

107 Sancti Augustini Vita Scripta a Possidio Episcopo, c. 28, 4, p. 112. "Verum brevi consequenti tempore divina voluntate et potestate provenit, ut manus ingens diversis telis armata et bellis exercitata, immanium hostium Vandalorum et Alanorum commixtam secum habens Gothorum gentem, aliarumque diversarum personas, ex Hispaniae partibus transmarinis navibus Africae influxisset et irruisset".

${ }_{108}$ Schmidt, Geschichte der Wandalen, 37, n. 3.

109 Procopius, 'De bello Vandalico', III, 10, 25, p. 98. 
who had joined the Vandals while still in Spain, this would offer evidence that the Gothic ethnic identity, and the distinctiveness of the people's members, survived in the Hasding state from the time of Genseric until the reign of Gelimer. Was Godas, however, a descendant of those Goths who had joined Genseric when in Spain? The problematic point is that this was not the only Gothic group known to us that lived within the Vandal kingdom's territory. In 500, or some time thereafter, Italic Ostrogoths, whose lord and master was Theoderic the Great (d. 526), appeared in the Vandals' state. The Vandal King Trasamund (d. 523) married to Amalafrida, Theoderic's sister, who arrived at the Vandal court assisted by "thousand of the notable Goths as a bodyguard, who were followed by a host of attendants amounting to about five thousand fighting men." 110 Is it possible that Godas could have been among the Ostrogoths accompanying Amalafrida? Or, was he perhaps one of the aforementioned Visigoths? There is no complete certainty about it, but there are strong indications against his being an Ostrogoth in Amalafrida's retinue, or a descendant of one of that group. Key to this end is the account of Procopius of Caesarea, whereby after Trasamund's death the new Vandal King Hilderic (reigned 523-30) imprisoned Amalafrida and killed all the Goths of her escort. ${ }^{111}$ If the Vandal monarch managed indeed to annihilate the entire Ostrogothic fraction, the only option remains that Godas's background was the Visigoths who joined Genseric while still in Spain. The fact that an issue of this people was considered a Goth into Gelimer's time attests that a Gothic identity and distinctness of this people persisted in the Hasding regnum for over a hundred years, from 429 - the date the Vandals went over from Spain to Africa - until the reign of Gelimer (from 530 on).

As is thus evident, the Goths and the Alani preserved their former ethnic distinctness within the Vandal regnum, never turning into Vandals. This challenges the argument claiming that members of foreign tribes turned into members of the local tribe after the conquest of a territory where the later resided: in other words, that the aliens were assimilated into, and assumed the ethnic identity of, the people being the background of their victorious king. The history of the Vandals offers a number of counterarguments with

${ }^{110}$ Ibidem, 8, 10-14, p. 76.

${ }^{111}$ Ibidem, 9, 3-5, p. 84. 
respect to the considerations proposed first by Schlesinger and, thereafter, by Wolfram.

Resuming the discussion on the character of ethnic identity in barbarian succession-based kingdoms, let us now tackle the questions: Was the ethnic identity instrumental, as Wenskus and his followers would have it? Or, should one, perhaps, agree with Murray and his putative inclination toward the primordial model, expressed in stating that it is indicated by the sources whether somebody was a Frank or Roman by birth? According to Procopius, Godas was undoubtedly a Goth by birth. Hence, there are strong indications that the birth criterion was, indeed, of importance for ethnic classification of barbarians in their kingdoms. Let us now take Agrivulf, a client of the Visigothic King Theoderic II (reigned 453-66), as an example (referring, this time, to the Visigoth kingdom area). A man of Varnian origin, as we are told by Jordanes (Varnorum stirpe genitus), ${ }^{112}$ and thus member of a foreign tribe, Agrivulf was nominated by the Visigoth king governor of the then-most recently conquered Suebi. The kingdom of the Ostrogoths also applied a classification with respect to origin and birth. One case in point is, e.g., an officer with King Totila, named Ragnaris, described by the East Roman historiographer Agathias of Myrina as not a kinsman or countryman of the Ostrogoths. ${ }^{113}$ Ragnaris was a member of the Bitugur people, who were a fraction of the Huns. ${ }^{114}$ In spite of his non-Gothic background, Ragnaris carved out an important position for himself among the Goths in the course of the wars against Emperor Justinian I (d. 565) and, around 554, was made commander of the Gothic contingent in the south of Italy. ${ }^{115}$ The three barbarians: Godas, Agrivulf, and

112 Iordanes, Getica, 233, p. 117. Edward A. Thompson has doubts with respect to the credibility of Jordanes's account with respect to Agriwulf's ethnic background; see idem, 'The Suevic Kingdom of Galicia', in idem, Romans \& Barbarians. The Decline of the Western Empire (Madison, 1982), 161-87, esp. 168-9 (first published in Nottingham Mediaeval Studies, xxi [1977], 3-31).

${ }_{113}$ Agathias, The Histories, trans. Joseph D. Frendo (Berlin, 1975), II, 13, 3, p. 45.

${ }^{114}$ For more on the Bitugurs, see Edward A. Thompson, A history of Attila and the Huns (New York, 1948), 156; Otto Maenchen-Helfen, The World of the Huns: Studies in Their History and Culture, ed. Max Knight (Berkeley, Los Angeles, and London, 1973), 438. According to this scholar, the Bitugurs set out in 488 for Italy, together with Theoderic the Great. If Maenchen-Helfen is right, the people in question has retained their distinctness and identity within the Ostrogothic state.

115 On Ragnaris, see Amory, People, 189-90, 408. 
Ragnaris, testify that 'tribal aliens' - albeit living among foreigners, and even if holding top posts - would not have rejected their ethnic identities and assumed new ones instead. Monarchs such as Gelimer, Theoderic II, or Totila - all being military kings, according to followers of the ethnogenesis model - did not make these tribal foreigners to become 'members of (their) tribe', losing their 'inherent' ethnic identity and assuming the ethnicity of their king. A question mark thus hangs over the argument whereby the ethnicity of early medieval barbarians was political in nature. There is also a question mark over the argument that the ethnicity of barbarian gentes was directly associated with political loyalty and dependence.

The three examples quoted above with respect to men of alien tribes in the kingdoms of the Vandals, Visigoths, and Ostrogoths show that none of them had to alter his ethnic identity and assume a new one in order to play an important part in the politics pursued by their barbarian kings or, as in the case of Ragnaris, gain a leadership position within a gens. Neither Godas nor Agrivulf accepted the ethnic identities of their respective rulers; nor did they adapt the ethnicities nurtured by members of the royal houses they served. Hence, the statement whereby the ethnicity of barbarians was a 'situational construct' and its alterations were, as a rule, meant to help achieve a material and/or political benefit, needs being approached with much caution.

\section{VI}

\section{ADOPTION AND SYMBOLIC CONSANGUINITY VERSUS ETHNICITY MODELS}

Should one reject the above-outlined theories of ethnogenesis, the question appears: So, what are we left with then? Can we possibly grasp the ethnic processes that took place in the post-Roman kingdoms, and discover the mechanisms that controlled the processes of formation of the barbarian peoples? To be frank, one comes to the conclusion that there is not much that can be done in this respect. However, a larger attention ought certainly to be paid to the consanguinity (consanguinitas) of late ancient and early medieval peoples: this 'symbolic kinship' existed in two forms, individual and group. ${ }^{116}$ Three examples of such relation can be specified. In Getica, Jordanes

${ }^{116}$ See Vernadsky, The Origins, 13. 
tells us of a kinship between the Gepids, the Ostrogoths, and the Visigoths. The symbolic consanguinitas linking the Visigoths and the Ostrogoths reflects, perhaps, the attempts at unifying the two peoples under the leadership of the Amal people, whose most eminent representative Theoderic the Great ascended also to the Visigothic throne in 511. ${ }^{117}$ The symbolic kinship between the Burgundians and the Romans, apparently a result of the actions of Roman diplomats, is the second example. Roman emissaries would have persuaded the Burgundians that they were the Romans' kinsmen, which resulted in the Burgundian warriors supporting Emperor Valentinian I in a war against Macrianus. ${ }^{118}$ The third example is the consanguinitas between the Vandals and the Alans, as reported by Sidonius Apollinaris. This author names the Alans the allies of the Vandals in the war; ${ }^{119}$ further on, he poetically names the Alani man a consanguine (consanguineus), or kinsman, of the Vandal. ${ }^{120}$ 'Symbolic kinship' could have possibly been a propagandistic instrument that facilitated the conclusion of political alliances between two ethnic groups and enabled their cooperation - or even, perhaps, enabled their unification under one monarch, as was the case with the Ostrogoths and the Visigoths of Theoderic's time. The condition or availability of original sources makes us confined to speculative deliberations.

Let us resume at this point the problem of the character of barbarian ethnic identities. As has been pointed out, scholars supporting the ethnogenesis model remark that barbarians altered their ethnic identities based on material and political benefits they could thus achieve. So far, however, no researcher has quoted any example of such altered ethnicity, which would have been based on an original source. ${ }^{121}$ But there is more to the problem with barbarian ethnic

117 See Robert Kasperski, Teodoryk Wielki $i$ Kasjodor. Studia nad tworzeniem "tradycji dynastycznej Amalów” (Kraków, 2013), passim.

118 John F. Drinkwater, The Alamanni and Rome 213-496: Caracalla to Clovis (Oxford, 2007), 109; Ian Wood, The Merovingian Kingdoms, 450-751 (London and New York, 1994), 34.

119 'Panegyric on Anthemius', II, 364, p. 38.

120 Ibidem, 369, p. 40.

${ }^{121}$ According to Pohl, the ethnic classification of Edica and his son Odoacer: "Ethnic boundaries are not static, and even less so in a period of migrations. It is possible to change one's ethnicity (otherwise the Indians would still be the only Americans we know). Even more frequently, in the Early Middle Ages, people lived under circumstances of ethnic ambiguity. We may cite Edica and his son Odoacer 
identities. It is oftentimes indicated that 'tribal foreigners' tended to be adopted into the tribe, becoming its members. Researchers such as George Vernadsky and Bernard S. Bachrach long ago drew attention to the account of Lucian of Samosata (c. 120 - c. 190), who, according to the latter scholar, may testify to what the ritual adoption among the Scythians was like. ${ }^{122}$ Does Lucian indeed attest that the Scythians practiced a ritual adoption indeed? (Bachrach would admit that the Alans also had to adapt prisoners-of-war.) Or, does his account prove to us that tribal aliens became Scythians through adoption? In his dialogue Toxaris (fr. 37), Lucian describes 'the blood-brotherhood' ritual among Scythians warriors. ${ }^{123}$ As such, this depiction cannot obviously be evidence that tribal aliens were included in this particular fashion into the tribe and that through such 'blood-brotherhood' a foreigner altered his ethnic identity. ${ }^{124}$

as striking examples; at different stages of their career they were taken to be Huns, Sciri, Turcilingi (or Thuringians), Rugians, Eruls, and even Goths, while Odoacer made his career as a Roman officer and eventually became king of Italy. We do not have to sort out the 'errors' from this list to arrive at an 'authentic' ethnic background; presumably, the two princes used a polyethnic background for widespread and flexible claims to the political loyalty of their partners and followers. However, they belonged to a social class in which ethnicity mattered", idem, 'Conceptions', 17. I am not certain, however, whether anything can be done with respect to such ethnic classifications of both chieftains, with such far-fetched conclusions drawn on this basis. Marcellinus Comes went as far as considering Odoacer king of the Goths (Odoacar rex Gothorum), a fact that adds to the complexity of the picture; Marcellinus Comes, Chronicon, sub anno 476, ed. Theodor Mommsen (MGH, AA 11, Berlin, 1894), 91. For a discussion on the ethnic origin of Odoacer, see Reynolds and Lopez, 'Odoacer', 36-53; Bruce MacBain, 'Odovacer the Hun?', Classical Philology, lxxviii, 4 (1983), 323-7, esp. 325, n. 13; Maenchen-Helfen, The World, 376-89. Also, see Edward A. Thompson, 'A.D. 476 and After', in idem, Romans, 61-76, esp. 61; MacGeorge, Late Roman Warlords, 284-6. These studies show the enormity of the problems to be tackled in discussing the ethnicity of this particular ruler.

122 Vernadsky, The Origins, 13; Bachrach, A History, 21.

${ }^{123}$ Karen ní Mheallaigh finds that Lucian based his depiction on Herodotus' description of the Scythians; eadem, Reading Fiction with Lucian: Fakes, Freaks and Hyperreality (Cambridge, 2014,) 65, n. 114.

${ }^{124}$ In an English translation, the ritual went on as follows: “... But before I begin, I should like to describe to you our manner of making friends. Friendships are not formed with us, as with you, over the wine-cups, nor are they determined by considerations of age or neighbourhood. We wait till we see a brave man, capable of valiant deeds, and to him we all turn our attention. Friendship with us is like courtship with you: rather than fail of our object, and undergo the disgrace 
With regards to the Early Middle Ages, the Sclavens and the Antes are good examples illustrating the adoption and inclusion of people of foreign tribes into the other gentes. ${ }^{125}$ As per Pseudo-Maurice's Strategikon (11.4), both peoples would keep prisoners captive for some, not too long, time. Afterwards, the Sclavens and Antes offered the captive a choice: go back home, or remain among them as free people and friends. ${ }^{126}$ Yet, Strategikon tells us nothing about altered identity or assimilation of those of 'foreign tribe'. So, did 'tribal foreigners' who remained amidst the Slavs tend to assume the tribal identity of the Sclavens or Antes? Would they reject, in parallel, their previous ethnic identity? Was it the case that all the borders between Sclaven (or Ante) people and the 'tribal foreigner', who become a friend of members of these people and decided to live among them, faded away? Can we find answers to these questions? Unfortunately, there is nothing certain about it. However, there are records that may provide us with a premise in favour of the view that there were people living among the Sclavens and the Antes who continued to be identified as 'tribal aliens'. Let us pay attention, for that matter, to the message conveyed by Theophylact Simocatta (6th/7th cc.) in his description of the Byzantine army campaigning against the Sclavens in the years

of a rejection, we are content to urge our suit patiently, and to give our constant attendance. At length a friend is accepted, and the engagement is concluded with our most solemn oath: 'to live together and if need be to die for one another'. That vow is faithfully kept: once let the friends draw blood from their fingers into a cup, dip the points of their swords therein, and drink of that draught together, and from that moment nothing can part them. Such a treaty of friendship may include three persons, but no more: a man of many friends we consider to be no better than a woman who is at the service of every lover; we feel no further security in a friendship that is divided between so many objects", Lucian, 'Toxaris', c. 37, in The Works of Lucian of Samosata, iii, trans. Henry W. Fowler and Francis G. Fowler (Oxford, 1905), 56-7. For the 'blood-brotherhood' custom in various cultures, see Walter Puchner, 'Adoptio in fratrem. Kirchliche Segnung der Wahlbruderschaft zwischen theologischem Verdikt und gelebter Pastoralpraxis', in idem, Studien zur Volkskunde Südosteuropas und des mediterranen Raums (Köln and Weimar, 2005), 353-70.

125 Peter Heather and John Matthews, The Goths in Fourth Century (Liverpool, 1991), 91.

${ }^{126}$ Das Strategikon des Maurikios, ed. George T. Dennis, trans. Ernst Gamillscheg (Corpus Fontium Historiae Byzantinae, 17, Wien, 1981), XI, 4, p. 373; Maurice's Strategikon: Handbook of Byzantine Military Strategy, trans. George T. Dennis (Philadelphia, 1984), 11, 4, p. 120. 
593-4. ${ }^{127}$ As we are told, "there was a certain Gepid amidst the barbarians [i.e. the Sclavens]" who deserted and joined the Byzantines. ${ }^{128}$ Let us notice that the Gepid living together with the Sclavens was continually identified as an alien - not a Sclaven, in any case.

Should we, therefore, completely reject the instrumental ethnicity model? The answer is, of course not. As anthropologists have shown many a time, 'tribal aliens' were admitted in blood-related groups, adopted by ruling houses, or even inserted in the ancestral pedigree lines. ${ }^{129}$ Nonetheless, adoption not in each case resulted in a complete abolition of the borders between a 'tribesman' and a (tribal) 'foreigner'. To clarify this problem, we have to move in time and space - from the early medieval kingdom of the Vandals to North America in the eighteenth/nineteenth century: there, the people lived whom Gary C. Anderson hailed as 'the masters of ethnogenesis'. ${ }^{130}$ The fact that Reinhard Wenskus often made use of the ethnographic material obtained through field research particularly by the investigators who worked amidst indigenous groups in North American territory (let us add that in the course of each of his four stays in the United States, the German historian visited Indian reservations and conducted his own research there ${ }^{131}$ ) is not the only incentive for us to revisit the history of the Comanche people. ${ }^{132}$ The Comanches

${ }^{127}$ On the dating of this campaign, see Florin Curta, The Making of the Slavs: History and Archaeology of the Lower Danube Region, c. 500-700 (Cambridge, 2004), 100.

${ }^{128}$ The History of Theophylact Simocatta, Eng. trans., introduction and notes Michael Whitby and Mary Whitby (Oxford, 1986), VI, 8, 13, p. 171. We regretfully are not competent enough to verify the opinion voiced by Samuel SzádeczkyKardoss, whereby traces of the Gepid population in Pannonia are traceable until 871-3; see idem, The Avars, in Denis Sinor (ed.), The Cambridge History of Early Inner Asia, i (Cambridge, 1990), 206-28, esp. 223.

${ }^{129}$ See Edmund Leach, Political systems of highland Burma: a study of Kachin social structure (Oxford, 1959), passim; Kirstin C. Erickson, Yaqui homeland and homeplace: the everyday production of ethnic identity (Tucson, 2008), passim.

${ }^{130}$ Gary C. Anderson, The Indian Southwest, 1580-1830: Ethnogenesis and Reinvention (Norman, 1999), 4.

${ }^{131}$ Beck, 'Wenskus, Reinhard', 455.

${ }^{132}$ For more on the history of the Comanche, see Ernest Wallace and Edward Adamson Hoebel, The Comanches: Lords of the South Plains (Norman, 1952), passim; Thomas W. Kavanagh, The Comanches: A History, 1706-1875 (Lincoln, 1999), passim; Stanley Noyes, Los Comanches: The Horse People, 1751-1845 (Albuquerque, 1995), passim; Pekka Hämäläinen, The Comanche Empire (New Haven, 2008), passim. 
are an example of a people who have shown an astonishing ability to absorb ethnically alien groups, which turned this once small tribe, in a relatively short time, into the 'Lords of the South Plains', as they are commonly called. ${ }^{133}$ However, the adoption of the 'tribal foreigners' did not lead to their complete loss of the 'alien' status. ${ }^{134}$ The Comanche differentiated between two categories of tribe member, one being the $n \mathfrak{t} m \mathfrak{m}$ rtborapt - 'our born-ones'135: as ethnologists tell us, this denoted Comanche people born out of their Comanche parents. ${ }^{136}$ The other category, described as numznaitu, included those 'living like the Comanche', ${ }^{137}$ which stood for anyone who was not a Comanche by birth (origin). Hence, the assimilation of 'tribal aliens' was not complete; nor was the borderline between 'our people' and 'aliens' completely abolished. ${ }^{138}$

The problem in question extended beyond those individuals who were adopted into the 'native' Comanche families: there were entire groups that did not completely assimilate with the Comanche. Let us glance, for that matter, on the Chariticas - the 'Dog-eaters'. ${ }^{139}$ Originally, they formed an Indian group of the Arapaho. ${ }^{140}$ Around 1813, they detached themselves from their tribesmen and began residing in the territory of the Kiowa and the Comanche. ${ }^{141}$ They were soon after accepted amidst these two allied peoples, and thus were deemed part of the 'Comanche nation'. The Chariticas dwelled together with the Comanche in mixed encampments, assumed their attires and war decorations; yet, the observers could still notice differences between members of the two groups. They namely observed that

133 Wallace and Hoebel, The Comanches, passim.

134 George L. Campbell, Compendium of the World's Languages (Oxon and New York, 2013), 444.

135 Ibidem.

${ }^{136}$ Morris W. Foster, Being Comanche: A Social History of an American Indian Community (Tucson, 1998), 22.

137 Campbell, Compendium, 444.

138 Hämäläinen, The Comanche Empire, passim.

139 About this group see Loretta Fowler, Arapahoe Politics, 1851-1978: Symbols in Crises of Authority (Lincoln, 1982), 15-16; Melburn D. Thurman, 'On the identity of the Chariticas (Sarii Rikka): dog eating and prehorse adaptation on the High Plains', Plains Anthropologist, xxxiii, 120 (1988), 159-70.

140 Nicholas J. Santoro, Atlas of the Indian Tribes of North America and the Clash of Cultures (New York, 2009), 118.

${ }^{141}$ Fowler, Arapahoe Politics, 16. 
the Chariticas were distinct from the Comanche "in their customs and their language, which is much harsher and without harmony". ${ }^{142}$ Although Chariticas, apart from their own dialect, used the language of their allies, they did not cease to be considered an Arapaho group by the Comanche: 'Chariticas' is the Comanche for the Arapaho people, to be specific. ${ }^{143}$

The Cheyenne is another object of study in the area of ethnogenetic processes taking place in North America. This people also displayed numerous assimilative processes embracing people of foreign tribes who were integrated into the tribal community through adoption or marriage. Did they turn, then, into full-fledged members of the Cheyenne people? As John H. Moore observes,

Although captives and adoptees were sometimes denied certain ritual roles because of their inability to speak Cheyenne, their Cheyenne-speaking children were full citizens. The basis of citizenship was not 'racial' or biological but was by birth in a Cheyenne band. ${ }^{144}$

Again, in this particular case, should one come to the conclusion that there was an essential difference by a Cheyenne-by-birth and somebody who had been adopted into the group?

Assimilation and acculturation is an extremely complex issue. Members of alien groups could be assimilated or included/integrated into a foreign tribal blood-related/kinsmen group, and assume an alien culture, but still not all the differences between the alien and the tribe member have been blurred. ${ }^{145}$ However, as the case of the Cheyenne shows, in contrast to their parents, children of such

142 Quoted after Hämäläinen, The Comanche Empire, 182.

143 De Benneville Randolph Keim, Sheridan's Troopers on the Borders: A Winter Campaign on the Plains (London and New York, 1885), 189; Thomas Jefferson Farnham, Farnham's Travels in the Great Western Prairies, the Anahuac and Rocky Mountains, and in the Oregon Territory (London, 1843), 266, n. 157.

${ }^{144}$ Quoted after Berndt, Kinship as Strategic Political Action, 46.

${ }^{145}$ For the terminology, let us cite Edward James: "Assimilation may be defined as an abandonment of ethnic distinctions and the acceptance by an incoming group of the cultural norms of the mainstream culture; acculturation is the bringing together of two cultural groups so that cultural elements may transfer from one to the other; accommodation is a process through which two societies or cultural groups work out a procedure whereby each group retains aspects of their own culture"; idem, Europe's Barbarians, 193. 
assimilated tribal foreigners enjoyed the status of fully fledged members of the group. Are there any decisive arguments that would make us unambiguously espouse the primordial model, or accept its instrumental counterpart? The truth is that the long-lasting dispute between the ethnologists has not come to a resolution - with the result that historians must humbly admit they cannot say they have a casting vote in this respect. ${ }^{146}$

\section{VII \\ CONCLUSION}

The present remarks have been voiced on the fringes of a debate that goes on around the ethnogenesis model, ethnicity, the history of early medieval barbarian peoples, and the related issues. Regarded as the father of the ethnogenesis model, Reinhard Wenskus ought no doubt to be assigned a much more modest role: he is the one who has synthesised several scientific theories that had grown on the grounds of considerations on the political system, religion, and history of early medieval gentes. The theory called today the 'ethnogenesis model' has been elaborated on the basis of a number of earlier propositions put forth by older scholars, Walter Schlesinger being one of them. Nevertheless, the ethnogenesis model calls for a further in-depth investigation, at the intersection of methodology and history of historiography. A number of problems still remain to be solved. Analysis is needed, at least, of whether the role of myth is comprehended within the ethnogenesis model in a functionalist take, the way Wenskus saw it, or one should rather agree with Murray, who rejects this option. ${ }^{147}$ More, perhaps, than the history of barbaric

${ }^{146}$ In the dispute between the followers of the idea whereby ethic groups are real and those believing that they have been socially constructed, ethnologists and sociologists tend to assume, with increasing frequency, an intermediate stance; see, e.g., Fenton, Ethnicity, passim. Such intermediate position begins gaining followers also in the dispute between adherents of primordial ethnicity and those advocating 'instrumental' (situational) ethnicity.

${ }^{147}$ Wenskus believed that the postulates of functionalists were an ideal investigative tool for his own analyses; see idem, Stammesbildung, 5. For a critical discussion, see Murray, 'Reinhard Wenskus', 50, n. 37. The issue under discussion is, obviously, extremely complicated and requires further in-depth research. Frank A. Weigelt thus writes of ethnogenesis as a functionalist concept: "In the 
peoples as such, the ethnogenesis theory calls for another thorough discussion. ${ }^{148}$

\author{
trans. Tristan Korecki
}

\title{
SELECTED BIBLIOGRAPHY
}

Geary Patrick, Before France and Germany: The Creation and Transformation of the Merovingian World (New York and Oxford, 1988).

Geary Patrick, 'Ethnic Identity as a Situational Construct in the Early Middle Ages', Mitteilungen der anthropologischen Gesellschaft in Wien, cxiii (1983), 15-26.

Goffart Walter, Barbarian Tides: The Migration Age and the Later Roman Empire (Philadelphia, 2006).

Halsall Guy, Barbarian Migrations and the Roman West, 376-568 (Cambridge, 2007). James Edward, Europe's Barbarians, AD 200-600 (Oxon and New York, 2014). Murray Alexander Callander, 'Reinhard Wenskus on "Ethnogenesis", Ethnicity, and the Origin of the Franks', in Andrew Gillett (ed.), On Barbarian Identity: Critical Approaches to Ethnicity in the early Middle Ages (Turnhout, 2002), 39-68. Schlesinger Walter, 'Über germanisches Heerkönigtum', in Theodor Mayer (ed.), Das Königtum. Seine geistigen und rechtlichen Grundlagen (Lindau and Konstanz, 1956), 105-41.

functionalist approach, the processes of creating ethnicity were defined in terms of the objective cultural structure and institutions of a given society. Ethnicity was a product of political myth, created and manipulated by sociocultural elites in their pursuit of advantages and power"; idem, 'Ethnogenesis', in Mark Juergensmeyer and Wade C. Roof (eds.), Encyclopedia of Global Religion (London, 2012), 369. Although the conviction has long been prevalent that functionalism is "as dead as a dodo" (Barry Barnes, The Elements of Social Theory [Princeton, 1995], 37), some scholars affirm that, as to certain aspects, its new embodiment may be the so-called 'invented tradition' theory. For instance, American anthropologist Marshall Sahlins states that the invented tradition theory is but a scientific déjà vu and nothing else than a repetition of the theory developed by Bronisław Malinowski. Sahlins says that invented tradition essentially boils down to Malinowski's 'mythical charters'; see Marshall Sahlins, 'Two or Three Things that I Know about Culture', The Journal of the Royal Anthropological Institute, v, 3 (1999), 399-421, esp. 403-12. It has, though, to be remarked that whilst Hobsbawm and his colleagues emphasised the symbolic aspect of invented traditions, Malinowski resolutely rejects the statement that myth is a symbolic narrative: "myth, as we shall see, is not symbolic"; Bronisław Malinowski, 'The Role of Myth in Life', in Alan Dundes (ed.), Sacred Narrative: Readings in the Theory of Myth (Berkeley and Los Angeles, 1984), 193-206; idem, Myth in Primitive Psychology (New York, 1926), passim.

${ }^{148}$ Murray's essay 'Reinhard Wenskus' exquisitely discusses the theory in question. 
Schlesinger Walter, 'Herrschaft und Gefolgschaft in der germanisch-deutschen Verfassungsgeschichte', Historische Zeitschrift, clxxvi (1953), 225-75.

Wenskus Reinhard, Stammesbildung und Verfassung. Das Werden der frühmittelalterlichen gentes (Köln and Graz, 1961).

Wolfram Herwig, 'Austria before Austria: The Medieval Past of Polities to Come', Austrian History Yearbook, xxxviii (2007), 1-12.

Wolfram Herwig, Die Goten. Von den Anfängen bis zur Mitte des sechsten Jahrhunderts. Entwurf einer historischen Ethnographie (München, 2009).

Wolfram Herwig, Gotische Studien. Volk und Herrschaft im frühen Mittelalter (München, 2005).

Robert Kasperski - medieval history; assistant professor at the Institute of History, Polish Academy of Sciences; e-mail: robertkasperski@gmail.com 